Longicorn Beetles of Japan. Additions, chiefly from the later Collections of Mr. George Lewis; and Notes on the Synonymy, Distribution, and Habits of the previously known Species. By H. W. BATES, F.R.S., F.L.S.

(Read 5th Jane, 1884.)

[Plates I. \& II.]

THE present paper is essentially a supplement only to a former paper published on the same subject in the 'Annals and Magazine of Natural History' for 1873, vol. xii.; but it is a supplement which in extent greatly surpasses the original, the number of species of this conspicuous Coleopterous family recorded in the first paper being 107 , and the present paper containing 129 , making a total of 236 species now known as belonging to the Japanese Fauna in this department. This great accession to our kuowledge is due almost entirely to the labours of Mr. Lewis and the native collectors directed by him, on his second visit to the islands in 1880-81. It is sufficient to glance at the two lists-the original one, published in 1873, and the following supplemental one-to see how large a proportion of the new species (and it is the same with the species known elsewhere now detected in Japan) is due to the labours of Mr. Lewis.

In the introductory paragraphs to my former paper I made a few remarks on the relations of the Fauna of Japan as regards the Longicornia to those of other regions, pointing out chiefly the very strong tropical element and the absence of many characteristic palæarctic genera. I have also discussed the question of faunistic relations in two other papers published on the Geodephagous Coleoptera of Japan. In my first enumeration of the Japanese Longicornia, I remarked that 21 genera out of the total of 64 were tropical genera, i. e. gtuera found nowhere but within the tropics. In the present supplement only 6 of the 57 genera added to the original 64 are known as tropical; but the number must be increased if we are to add the many absolutely new genera (such as Leptoxenus, Pyrrhona, Corennys, Xenicotela, \&c.), which have tropical, and not palæarctio, affinities. Still, upon the whole, our supplementary list must be considered as diminishing the proportion of tropical forms in the Longicorn Fauna of Japan, a large number of European, Siberian, and NorthIINN. JOURN.-ZOOLOGY, VOL. XVIII. 
American genera (e. g. Asemum, Tetropium; Rhagium, Encyclops, Pachyta, Grammoptera, Gaurotes, Strangalia, Necydalis, Rosalia, \&c.) having been now found, and many of the absolutely new genera having palæarctic or nearctic rather than tropical affinities. We know at present too little of the productions of the neighbouring regions of Asia ( $i, e$. Corea, Manchuria, and Northern China), to discuss profitably the interesting problems which the Insect-fauna of Japan presents, such as its true relations to the neighbouring temperate parts of the Asiatic continent and the more distant tropics, and the derivation of the extraordinary number of endemic forms which it seems, especially as regards the Longicornia, to contain. Mr. Lewis's recent journey has shown, amongst other things, that the tropical forms are not confined to the southern part of the islands, nor the boreal forms to the northern part; from what we know of the same departments of the Fauna of Manchuria, tropical forms do not seem to extend northwards in the same way in continental Asia.

List of Species, supplemental to that published in the 'Annals and Magazine of Natural History,' vol. xii. (1873).

Fam. Prionid

Psephactus remiger, Harold.

Fam. CERA M B Y CI D $\boldsymbol{A}$.

Megasemum quadricostulatum, Kraatz.

Asemum amurense, Kraatz.

Tetropium luridum, Linn.

Neocerambyx Batesi, Harold.

Allotræus sphærioninus, Bates.

Leptoxenus ibidiiformis, Bates.

Rhaginm inquisitor, Linn. (var. japonicum).

Xenophyrama purpureum.

I.emula decipiens.

Encyclops olivaceus.

Omphalodera Puziloi, Blessig.

Pachyta erebia.

Gaurotes doris.

Toxotinus longicornis.

Grammoptera ægrota.

- grallatrix.

- _ signifera.

- amentata.

- chalybeella.

Leptura misella.

- pyrrha. succedanea, Lewis.
Leptura variicornis, Dalm.

- granulata.

- excavata.

- cometes.

- vicaria.

- mimica.

- subtilis.

- thoracica, Creutz.

- adumbiata.

- nymphula.

Strangalomorpha ænescens.

Eustrangalis distenioïdes.

Strangalia dulcis.

- contracta.

- regalis.

Pyrrbona læticolor.

Corennys sericata.

Necydalis solida.

_- ebenina.

- _ pennata, Lewis.

Aromia ambrosiaer, Steven.

Chloridolum thaliodes.

- quadricolle.

Callichroma (?) japonica, Harold.

Rosalia Batesi, Harold.

Rhopalopus signaticollis, Solsky.

Semanotus chlorizans, Solsky.

Phymatodes Maaki, Kraatz.

Plagionotus pulcher, Blessig. 
Clytanthus gracilipes, Falderm. latifaseiatus Fischer: misellus. xeniscus.

Demonax transilis

Clytus melænus.

- auripilis.

Xylotreehus chinensis (Chevr.).

- enaciatus.

- clarinus.

- albifilis.

-_rufilius.

Brachyclytus singularis, Kraatz.

Anagly tus niponensis.

Paraclytus excultus.

Aglaophis colobotheoïdes.

Fam. LA M I D I A.

Phlyctidola metallica.

Echthistatus binodosus, Waterh. furciferus.

- grossits.

Dolophrades terrenus.

Monohammus nitens.

- grantis, Waterh. pardalinus.

Haplohammus fulvicornis, Pascoe.

Uracha griseola.

Mecunippus pubicornis.

Apalimna liturata.

Xenicotela fuscula.

Rhodopis integripennis.

Nanohammus rufescens.

Seotin quges diphysis, Pascoe.

Mesosa gracilior.

M lirsuta.

- senilis.

— poecila.

— cribrata.
Mesosella simiola.

Sybra subfasciata.

Xylariopsis mimica.

Sydonia divaricata.

Graphidessa venata.

Eupogonius tenuicornis.

Terinæa atrofusca.

Cylindilla grisescens.

Rhopaloscelis unifasciatus, Blessig.

- maculatus, Bates.

- bifasciatus, Kraatz.

Eryssamena saperdina.

- acuta.

- spinidorsis.

Miccolamia cleroïdes.

-C- verrucosa.

- glabricula.

Clytosemia pulchra.

Acanthocinus stillatus.

Callapœeus guttatus.

Agapanthia angusticollis, Gyll.

Saperda decempunctata, Gebler.

- tetrasticta, Bates. sulphurata, Gebler.

- octomaculata, Blessig.

Eutetrapha variicornis.

- chrysargyrea.

Paraglenea chiysochloris, Bates.

- eximia.

- theaphia.

Glener colenda, Thomson.

Singalia rufescens.

Stenostola argyrosticta. anomala.

Épiglenea comes.

Oberea vittata, Blessig.

-.- niponensis.

- sericans.

Praolia citrinipes.

\section{Fam. Priontda.}

Psepiactus reyiger, Harold, Deutsch. ent. Zeitschr. xxiii. (1879) p. 367, ㅇ. (Plate I. fig. 3. $\sigma^{7}$ )

o. Minor et angustior; antennis haud longioribus, articulis 3-11 late (tertio latius) dilatatis et compressis; elytris adhuc brevioribus, segmentum primum ventrale paullo superantibus, supra crebrius reticulato-punctatis; tibiis posticis dilatato-compressis. Long. of 16 millim., of 25 millim.

Yezo, not rare. At Junsai found emerging in some numbers from a moss-grown stump. 
The genus Psephactus, as Harold observed, is allied to Tragosoma. The genus of the Tragosominæ group to which it approaches the nearest is Sarmydus, Pascoe.

Agosoma sinicum, White.

Found in Yezo and in Central Japan.

\section{Fam. CERAM B YOID}

Megashmom quadricostulatum, Kraatz, Berl. ent. Zeitschr. xxiii. (1879) p. 97.

Chiuzenji, and Sonth Yezo. Common in July and August. Described by Kraatz from East Siberia. Japanese cxamples are generally larger than the size (24 millim.) given by Kraatz, averaging 27 millim.

Asemom AMUREsse, Kraatz, Deutsch. ent. Zeitschr. xxiii. (1879) p. 97.

Nikko.

Kraatz's brief description agrees with the Japanese specimens as far as it goes; but, if his species be really the same, the differences from the European A. striatum seem more important than he allows, the elytra being relatively more elongated and the thorax conspicuously different in its moderately rounded and not angulated sides.

Tetropium LuRidum, Linn. Syst. Nat. ed. xii. p. 634.

Tokio. One large specimen, Jong. 18 millim. The species is found throughout Northern and Central Europe and Siberia to the coast of Manchuria.

Neocknasbyx chrysothrix, Bates, Ann. \& Mag. Nat. Hist. ser. 4 , xii. p. 152 , ㅇ․

o. A fomina differt tantum antennis corpore fere duplo longioribus, articulisque 3-5 apice incrassatis.

Tokio.

The 3rd-5th joints of the antennæ are moderately clavate or thickened at their apices, the 5th slenderer than the two others and slightly longer than the 3rd.

Nhocerambxx Batesi, Harold, Abhandl. Nat. Ver. Bremen, iv. p. 295 (1875).

Japan.

The description, drawn up from a male example, fits almost 
exactly $N$. chrysothrix of, with the exception that the 3rd-5th antenual joints are not clavate (at least the author makes no mention of that feature) and the size much larger, 32 millim., N. chrysothrix measuring 25 millim. only.

Pachydrssug (Mallambrx) Japonicus, Bates, Ann. \& Mag. Nat.Hist. ser. 4, xii. p. 152.-Neocerambyx Raddei, Blessig, Horce Soc. Ent. Ross. ix. p. 170, t. vii. fig. 1.

Althongh the description and figure of Blessig do not exactly fit with regard to the outline of the thorax and the sutural apex of the elytra (especially in the female), there can be little doubt that the two names refer to the same species.

Central Japan; Yezo.

Aldotraus sphzioninds, Bates, Ent. Monthly Mag. xiv. (1877) p. 37 .

Hitoyoshi.

Leptoxents ibIDIIformis, Bates, Ent. Monthly Mag. xir. (1877) p. 37.

Taken commonly as far north as Idzu.

Stenterinum quadrinotatum, Bates, Ann. $\&$ Mag. $N . H$. ser. 4 , xii. p. 154 .

Ipongi; Japan. The species occurs also on the Khasia Hills.

Distenta japonica, Bates, Ann. \& Mag. $N$. H. ser. 4, xii. p. 155.-A pheles gracilis, Blessig, Horo Soc. Ent. Ross. ix. p. 200, t. viii. fig. 1.

Blessig describes his species from a single example found at Port May, on the coast of Manchuria; his description and figure agree with the Japanese species, which is not generically different from $D$. columbina, Serv, the type of the genus. Biessig mentions as a chief character of Distenia silky hairs on the underside of the antennæ; but these do not exist in $D$. coiumbina, at least in the examples $I$ have examined, and cannot besides be a generic character, as they are present or absent in species most closely allied in all other respects.

Central Japan; Yezo.

RHaGium INQUisitor, Linn. (indagator, Fab.), var. JaPoNICUM.

A typo differt elytrorum maculis fulvis discretis transversis 
perparum confluentibus, fasciis duabus fulvis, sed fasciis fuscis plerumque vix perspicuis. Long. 12-16 millim.

Osayama and Niohozan.

Presents a different appearance from the European $\boldsymbol{R}$. inquisitor, owing to the tawny spots of the elytra being nearly always separate, exposing more of the shining brassy-black groundcolour. The spots in most examples are condensed into two widely separated fascix. A fascia of the dark ground-colour sometimes shows behind the second tawny belt. Examples, however, occur which do not differ from European specinens.

\section{Xenopitraama, nov. gen.}

Gen. Rhamnusio (Latr.) approximans. Corpus oblongum. Caput quadratum, ante oculos parum elongatum (sed mandibulis elongatis), genis post oculos elongatis rectis vel postice subdilatatis, ab angulis oblique ad collum angustatis ; collo parum constricto, vertice post antennas depresso, bituberoso, tuberibus (sicut tuberibus antenniferis) a linea dorsali profunda separatis; oculi subgrosse granulati sat profunde sinuati; tubera antennifera valida, elevata. Antennæ ( $q$ ) sat graciles fere enrporis apicem attingentes, prope oculorum marwinem anticam inserta; articulis 3-4 conjunctis quam $5^{\text {mus }}$ vix longioribus, 5-11 filiformibus, æqualibus. Thornx amorphus: apud apicem augustus et sulcato-constrictus, deinde subito dilatatus et usque basin figuram. cuboideam efficiens, dorso ntrinque in tuber magnum, apice concavum, sicut inflatus; lateribus utrinque ante medium prominens; basi sulcato-depressus angulis posticis fere rectis. Elytra convexa sat late elongato-oblonga, apice late rotundata. Prosternum inter coxas angustissimum haud perspicuum, coxis valde exsertis. Pedes sat graciles, posticis relative baud longioribus, tarsis posticis brevibus, articulo primo lineari, quam 2-3 conjuncti longiori.

Although totally different in facies, due to the broad oblong elytra, opaque surface, longer antennæ, \&c., this genus is undoubtedly allied to Rhamnusium.

Xenophyrama purpureum, n. sp. (Plate I. fig. 1.)

Nigrum, subnitidum; elytris rufo-purpureis, opacis, breviter incumbenti-pilosis, crebre subrugulose punctatis; capite thoraceque subtiliter sparsim punctulatis ; scutello nigro, hirsuto; corpore subtus subtilissime punctulato et griseo-pubescenti. Iong. 20 millim. $\delta$.

Yuyama ; one example, June 1st, 1881. 


\section{Toxotus candleipennis, Bates.}

Taken in Yezo.

Enctolops olivaceus, n. sp. (Plate I. fig. 7.)

Elongatus, linearis, olivaceo-æneus, subtiliter (capite thoraceque densius) griseo-pubescens, antennis pedibusque testaceorufis nigro-maculatis. Capite et thorace creberrime alveolatis, illo postice tumido.quadrato, oculis intus haud profunde sinuatis; hoc medio utrinque tuberculo conico, antice et postice parum constricto; disco modice convexo; elytris passim diserete punctatis ; pectore argenteo-pubescenti. Long. $7 \frac{1}{2}-10$ millim.

Chiuzenji and Omine.

Differs from the North-American genus Encyclops only in the shallower emargination of the eyes. In this respect it agrees better with Microrhabdium, Kraatz, of $\mathrm{I}$. Siberia; but Kraatz does not mention the finely faceted eyes, by his silence leaving. it to be inferred that in his genus they are coarsely faceted, as is Xylosteus, Psilorhabdium, and Leptorhabdium, with which alone he compares it. The terminal joint of the palpi is short and strongly securiform, the antennæ are inserted nearly opposite the midule of the eyes; the tarsi are all slender, the first joint very elongated, in the hinder feet longer than the remaining joints taken together. The close, sballow, alveolate punctuation of the head and thorax speaks, in addition to other structural similarities, for the generic union of the species with Encyclops. The antenne are red in their four basal joints, with the tips black (the scape having a long black streak), and black in the otber joints with the base of each red. The legs are red, with a long spet on the femora, a smaller one on the tibix, and the tips of the tarsi black.

LEMULA, nor. gen.

Corpus minus elougatum, convexum. Caput post oculos quadratum, ante oculos breve; oculi prominentes intus haud emarginati subtiliter granulati. Antennæ media fronte contra oculi marginem anticum insertæ, corpore breviores, filiformes, articulis 3-4 subæqualibus, 4-11 paullo longioribus; palpi articulis ultimis haud dilatatis. Thorax utrinque tuberculo conico armatus; elytra apice obtuse rotuudata, pygidium tegentin. Prosternum inter coxas nullum; mesosternum angustissimum. Pedes 
parum elongati; femora gradatim sed parum incrassata; tarsi postici breves.

The species on which this genus is founded resembles a moderately slender Lema. It is distinguished from allied genera by the combination of characters furmished by the tumid-quadrate hind part of the head, entire eyes, antennæ inserted away from the eyes on an elevation in the middle of the forebead formed by the antenniferous tubereles, which are separated only by an impressed line, and the rather short legs.

IAEMULA DECTPIENs, n. sp. (Plate I. fig. 5.)

Nigra; elytris, femoribus basi ventrisque apice, plus minusve fulvis, antennis rufo-fuscis. Capite et thorace nitidis sparsim pubescentibus disperse punctatis; illo medio linea impresso, hoc antice transversim profunde sulcato, postice depresso, disco bi-mamillato, sulco dorsali profundo ; elytris passim crebre punctatis, nitidis, breviter setosis. Long. $5 \frac{1}{2}-7$ millim.

Hab. Miyanoshita; Kiga.

Ompinalodera Puzilor, Blessig, Hore Soc. Ent. Ross. ix. p. 245.

Var. Corpore subtus toto flavo (O. flaviventris).

Oyama; Miyanoshita; Nikko; Suyrma. Described by Blessig from R. Suifun, F. Siberia.

The Japanese examples differ from Blessig's description in having the abdomen constantly yellow instead of black. As they agree in all other points, I cannot but conclude this to be a slight local variation.

Pachita frebia, n. sp.

․ Pachytis typicis, elytrorum apicibus truncatis utrinque bidentatis, pertinet. Nigra, obscura, opaca, argenteo-griseo pubescens, elytris fere glabris; antennis, capite et thorace sicut in $P$. quadrimaculata; elytris apice latius truncatis, supra grossius et profundius confluenter subrugose punctatis, nigris vitta brevi (a medio usque prope apicem) intramarginali rufofulva. Long. 22 millim. $q$.

Chiuzenji; one example.

Gaurotes doris, n. sp.

G. ussuriensi (Blessig) proxime affinis et simillima, sed differt abdomine semper flavo basi et lateribus nigro-maculato. Supra læte æneus, viridi-æneus vel auratus fere glaber, nitidus, breviter 
griseo-pubescens, subtus niger densius griseo-pubescens, abdomine flavo nigro-maculato; pedibus nigris nitidis; femoribus dimidio basali tibiisque (interdum) medio flavis. Capite creberrime thorace paullo parcius punctatis, elytris confluenter vel rugulose punctatis apice sinuato-truncatis utrinque bidentatis. Femora ơ omnia, $q$ \& posteriora subtus dentata. Long. 12-13 millim. o 9 .

Chiuzenji ; Niohozan.

Differs from $G$. ussuriensis (Blessig) of the Amur region only in the yellow colour of the abdomen, and would perhaps be better considered as a local variety of that species. It is, however, a larger and more brightly-coloured insect. The conspicuous tooth beneath the femora, similar to that of many Donacia, which both species wonderfully resemble, appears not to have been noticed by Blessig and Kraatz, the two authors who have mentioned G. ussuriensis: a specimen I obtained from probably the same source as those authors has femora like the Japanese form.

Toxotrus, nov. gen.

Facies gen. Toxoti. Caput post oculos elongatum paullulum tumidum sed vix ad collum angustatum, antice verticale. Oculi prominentes, parum emargiuati, a mandibulis sat distantes, subtiliter granulati. Palpi apice minime dilatati. Antenuæ of $q$ corpore longiores, articulis 3-4 subæqualibus quam 5-10 paullo brevioribus, undecimo multo longiori, contra oculorum marginem anticum insertæ; tubera autennifera elevata. Thorax relative parvus conoideo-subcylindricus, antice et postice modice constrictus, tuberculo laterali utrinque obtuso, angulis posticis nullomodo prominentibus. Elstra postice paullo attenuata apice rotundata. Prosteruum inter coxas angustissimum, mesosternum oblongum subconvexum. Pedes fere sicut in Toxotis, sed tibiis posticis apice multo minus oblique truncatis.

Distinguished from the allied genera by the form of the posterior part of the head and by the forehead being abruptly vertical from the base of the antennæ. The male resenbles at first sight small individuals of the same sex of Toxotus meridianus.

Toxotinds tongiconnis, n. sp. (Plate I. fig. 6.)

Elongatus, postice modice angustatus dorso subplaratus, supra dense subtiliter aureo-pubescens, pube thoracis longiori, incumbenti, lætius aurato; subtus griseo-pubescens. Fulvus, capite, 
scapo, thorace, sternis, coxis, trochanteribus femoribusque 4 posticis apice, nigris ; capite thoraceque creberrime subalveolatopunctatis, elytris discrete punctulatis. Long. 12-14 millim. o웅.

Oyama; May 1880.

\section{Grammoptera agrota, n. sp.}

G. debili (Kraatz) proxime affinis. Pallide flavo-testacea, pubescens, elytris præcipue dense flavescenti-lirtis, antennarum articulis (a quarto) apice, femoribus tibiisque posterioribus apice, tarsorum articulis apice, nigro-fuscis; capite postice gradaticn rotundato colio angusto, discrete punctulato, thorace sat angusto, versus apicem angustato, postice parallelogrammico angulis posticis subrectis, dorso valde convexo, sat sparsim subtiliter punctulato, linea dorsali brevi; elytris passim discrote punctatis, apice singulatim rotundatis. Long. 7-8 millim. $\delta q$.

Nikko; Hitoyoshi, and other localities.

Kratz descrives the head and thorax of his $G$. debilis from East Siberia as "äusserst dicht und fein punetirt." Were it not for this clearls expressed character, I should bave considered the present species the same as his; but the head and thorax in $G$. agrota are very much less closely punctulate than is usual in the allied species; there are even wide spaces on the thorax, smooth and shining, without punctures. The species has slender anteunæ and legs like $G$. debilis.

Gramaroptetia araliatrix, n. sp.

G. gibbicolli (Blessig) affinis et quoad colores simillima, sed differt corpore, pedibus antennisque multo magis elongatis, elytris truncatis ete. Valde elongata, sublinearis, testaceo-fulva flavopubescens, vertice (et collo supra), pronoti disco, elytrorum fascia angusta suturali, altera interrupta marginali, femoribusque dimidio apicali, nigro-fuscis; antennis valde elongatis et gracilibus (articulo quinto cæteribus longiori, quarto breviori), articulis a quinto apice fuscis ; capite post oculos breviter quadrato, paullo angustato sed angulis cistinct is colloque abrupte angustato, genis apud angulos (ut supra visis) flavis; thorace sat angusto, lateribus ante medium haud prominentibus, disco rotundato-convexo; crebre alveolato-punctato, pube aureo-sericeo incumbenti læto vestito; elytris of fere linearibus postice paullo angustatis, apice acute truncatis, extus angulatis, supra crebre punctatis; 
pectore lateribus argenteo-pubescenti, metasterno extus fusconigro; tarsorum articulo unguiculari nigro. Long. 12 millim. $\delta$.

Nikko. Several examples of both sexes, exactly similar in colours and markings.

In G. gibbicollis the enlarged posterior part of the head is not tumid, but gradually narrowed, and the convexity of the thorax is compressed posteriorly ; in G.grallatrix the posterior part of the head is distinctly quadrate and short, and the disk of the thorax forms an even convexity without compression. Both species are congeneric with Acmeops ligata, Lec., and other North-American species referred by American authors to the genus Acmeops.

Grammoptera signifera, n. sp.

․ G. gibbicolli iterum affinis. Paullo gracilior, nigro-fusca, partibus oris, clypeo, coxis femoribusque basi, testaceo-flavis; tibiis 4 anterioribus antennisque basi fusco-rufis, elytris utrinque vittis duabus (altera maryiuali altera discoidali) paullo aute apicem terminatis fasciaque ante apicem, fulvo-testaceis ; capite et thorace creberrime puuctatis, illo post oculos usque ad collum rotundato-anguslato, hoc disco valde convexo, convexitate postice perparum compresso ibique pilis flavo-sericeis convergentibus; elytris $(\delta q)$ sublinearibus apice truncatis (angulo exteriori rotundato), supra crebro sed discrete punctatis; abdomine fulvo, nigro-maculato. Long. 8-10 inillim.

Var. . . Fascia ante-apicali deest (thoracis marginibus anticis et posticis scutelloque falvis).

Vur. ? o. Multo minor, vitta discoidali cum fascia conjuncta, pedibus (tarsis exceptis) toto fulvis. Long. 6-7 millim. $\sigma^{*}$.

Var. + (G. mutata). Elytra fulva, vitta angusta suturali ante apicem terminata (ibique macula triangulari), maculis tribus utrinque marginalibus apiceque uigris, thoracis marginibus anticis et posticis, autennis et pedibus fulvis. Long. 10 millim.

Var. ․ Eadem: sed vitta suturali multo latiori, femoribus 4 posticis apice, antennis (basi excepta) nigris.

Nikko; Oyama; Hitoyoshi.

\section{Gramioptera amentata, n. sp.}

G. signiferce affinissima; differt capite post oculos recte angustato, postice (aute collum) distincte sed obtuse angulato, elytris ㅇ apice singulatim rotundatis, of obtusissime truncatis. Magis convexa, fusco-nigra, partibus oris, antennarum articulis basa- 
libus pedibusque rufo-testaceis, femoribus apice tarsisque plerumque nigris; elytris plaga utrinque elongata maculas ovales fusco-nigras duas includenti, apicem haud attingenti, fulva. Long. 6-8 $\frac{1}{2}$ millim. 0 . 9 .

Var. a. $\delta$ 오. Elytrorum plaga fulva laterali usque ad apicem continuata maculas tres includenti.

Var. $b . \sigma^{\circ}$. Elytris fulvis, sutura angusta maculisque utrinque tribus nigris; pedibus et interdum antennis pallide fulvis.

Miyanoshita; Suyama; Oyama; Chiuzenji.

Grammoptera chatybeeli $\Lambda$, n. sp.

G. ruficorni simillima. Gracilis, chalybeo-nigra griseo-pubescens, elytris subolivaceis nitidioribus et minus dense pubescentibus; antennis nigris, partibus oris, femoribus tibiisque anticis fulvo-rufis; thorace sicut in G. ruficorni. Long. 6-7 millim.

Nikko.

\section{Lettura miselia, n. sp.}

Ad $\S$ Anoplodera pertinet, sed corpore multo breviori fere sicut in $L$. livida. Subtus nigra, argenteo-griseo pubescens, supra nigra subopaca, nigro-setosa, elytris nitidis testaceo-fulvis, basi excepta nigro-marginatis, palpis et femoribus rufis (tibiis anticis rufescentibus); capite ante oculos parum prolongato sat lato, post oculos brevi, collu valde constricto, crebre subalieolatopuuctato; thorace angusto postice haud constricto, sicut capite punctato; elytris relative brevibus dorso planatis, apice rotundatis, discrete punctatis ; antennis filiformibus sat robustis, $\delta$ corpore l.ngioribus, $q$ multo brevioribus. Long. $5 \frac{1}{2}-7$ millim.

Kashiwagi ; Wada-togé.

The species is found also on the Amur, but is not noticed in Kraatz's excellent memoir on the Longicornia of that region.

\section{LETTURA PYRRHA, n. sp.}

L. tesserula proxine affinis, differt solum elytris rubris immaculatis. Brevis, nigra subopaca, subtus griseo-pubescens, supra fulvo-hirta, elytris rufo-miniat is sat conspicue discrete punctatis subnitidis, apice oblique truncatis ; thorace ænescenti-nigro, convexo, discrete punctato, juxta basin constricto et depresso; capite sicut in $L$. tesserula, postice brevi, angulato. Long. 11 millim.

Wada-togé; Nikko. 
Leptura succedanea, Lewis, Ann. \& Mag. N. H. ser. 5, iv. p. 464 .

Sapporo.

Mr. Lewis described the female only, mentioning the points in which it differs from the very closely allied European L. rubra (Linn.). The males of the two species differ more conspicuously, the thorax above in the Japanese form (except a trausverse spot at the base) being tawny red, like the elytra, and in L. rubra black.

Leptura varifcorists, Dalman in Schönh. Syn. Ins. i. 3. p. 482 .

Niohozan.

Found also in Eastern Siberia and thence to North-eastern Europe. Besides typical specimens, Mr. Lewis touk a single example of a black variety on Niohozan.

Leptura grandlata, n. sp.

Robusta, opaca, nigra, elytris obscure rufis; capite mox pone oculos constricto ; thorace medio late rotundato, basi valde constricto angulis haud productis, disco convexo inæquali, cum capite grosse rugoso-punctato; pilis incumbentibus aureis; ely tris modice elongatis et atlenuatis, apice haud oblique sinuato-truncatis angulis acutis ; tota superficie crebre granulata ; subtus rugosopunctulata tenuiter griseo-pubescens. Long. 17-23 millim. of 오 ․

Sapporo; Yani.

A large robust species, with thorax still more rounded on the sides than L. proxima (Say). The head behind the eyes is extremely short, showing only a small shining tubercle before the deep constriction of the neck. The pubescence is short and adpressed.

Leptuda ctavea, Gebler, Nouv. Mém. Mose. ii. p. 70.

Niohozan. Widely distributed in Eastern Siberia.

Leptura excavaTA, n. sp.

$L$. cyanea affinissima sed differt corpore relative breviore coloreque toto nigro. Postice parum angustata, nigra, elytris subnitidis medio ad suturam concavis, pone scutellum margine utrinque valde elevato, apice recte truncatis, angulo exteriori rotundato, suturali acuto, sat grosse et crebre (versus apicem 
subtilius) punctatis; thorace quam in L. cyanea paullo breviori lateribus perparum rotundatis, basi modice constricto, angulis haud prominentibus, disco convexo crebre foveolato, erecto piloso; antennis pedibusque breviter pilosis. Long. 12 millim.

Wada-toge; Niohozan.

Leptura (Jodolia) cometes, n. sp.

L. cordiferce (Oliv.) affnis : major, dense fulvo-pubescens, nigra opaca, elytris testaceo-flavis, basi juxta scutellum, macula subrotunda utrinque laterali (post medium) alteraque apicali, nigris; thorace campanuliformi, basi depresso, augulis maxime productis, dorso creberrime punctato dense erecte pubescenti ; elytris sicut in $L$. cordiferce apice singulatim productis subacutis, densissime sericeo subincumbenti-pubescentibus. Long. 15 millim.

Chiuzenji; Niohozan; Sapporo.

Approaches the North-American $L$. (Judolia) cordiferc more nearly than any of the European species, having similarly prolonged apices of the elytra; but it is very much larger, and wants the anterior marginal spot of the elytra. The plossy tawny-golden pubescence on the elytra conceals, in certain lights, the black spots.

\section{LeptURA (STENTRA) VICARTA, n. sp.}

L. obliterate (Haldem.) quam proxime affinis; differt statura Iongiori et graciliori, tibiisque posticis (o) nigris etc. Nigra, fulvo-aureo pubescens; capite antice testaceo-favo, macula triangulari frontali epistomateque nigris; thorace utrinque paullo ante medium tuberculo conico, crebre punctulato, fulvo-testaceo plaga magna dorsali nigra; elytris quam in $L$. obliterata longius attenuatis, basi relative angustioribus, apice oblique sinuatotruncatis utrivque bidentatis, flavis, apice late, fascia recta mediana maculaque parva versus basin laterali, nigris: antennis ( $\sigma^{*}$ ) corporis apicem fere attingentibus, nigris, scapo subtus articulisque apicalibus basi flavis; pedibus flavo-testaceis, tibiis posticis $(\delta)$ femoribusque (basi excepta) nigris.

б. Tíbiis posticis dimidio basali flavis; elytris apice flavis (fascia subapicali nigra); antennarum articulis omnibus (a quarto) pallidis.

Long. 17-20 millim. $d$ ㅇ․

Niohozan and Sapporo; on flowers of Hydrangea. 
Leptuda (Stendra) Mimica, n. sp.

$L$. arcuate affinissima, differt tantum antennis longioribus, coloribus signaturisque paullo diversis.

6. Nigra, pube incumbente, supra fulvo-aurea, subtus argentea, vestita; elytris utrinque fasciis sat "tenuibus flavis quatuorprima virguliformi juxta scutellum (ramo exteriori curvato deficienti), secunda, tertia et quarta sicut in $L$. arcuata ; antennis articulis $7-11$ fulvis.

․ Elytris fulvis, margine angusto basali et suturali, maculis rotundatis utrinque duabus (prima versus humeros interdum divisa, secunda majori apud medium) fasciisque duabus (prima ante apicem, secunda apicali) nigris ; antennis fulvis, scapo paullo obscuriori; pedibus nigro-fuscis, tibiis et tarsis 4 anterioribus fulvis.

Iong. 15-17 millim.

Var. $\delta$. Elytris nigris, maculis parvis duabus basalibus, altera medio basis, altera subhumerali.

Sapporo; Junsai; Nikko. The rariety is from Nikko.

Scarcely more than a local rariety of the Europen $L$. arouata, which is found with little variation throughout Eastern Siberia to the coast of Manchuria. The Japanese form differs from European and Siberiim examples chiefly in the basal fascia of the elytra in the male wanting the outer horn of the bow, and in the first and second black fiscim in the fumale being widely detached from the suture. The antennæ are longer, and the thorax more angulated on the sides.

\section{Leptura (Stentra) subtilis, n. sp.}

L. quadrifasciata (L.) affinis et similis, sed differt thorace basi multo lationi lateribusque subrectis haud sinuatis etc. Nigra, subnitida, elytris fasciis angustis quatuor suturam attingentibus et versus marginem angustatis; antennis subserratis; thorace triangulari multo subtilius punctato, fulro-aureo pubescenti; elytris subtilissime punctulatis et rugulosis apice recte truncatis, angnlis acutis, exteriori producto spiniformi. Long. 17 millim. ơ.

Chiuzenji, August 1881.

Differs from $L$. quadrifasciata, which occurs throughout Eastern Siberia as well as Northern and Central Europe, by definite specific characters; the thorax being regularly and straightly dilated from the fore margin to the hind angles, the angles of the elytral truncature spined, and the yellow fascio different in form. 
Leptura (Stendra) thoracrca, Creutzer, Ent. Vers. p. 125 ; Fabr. Syst. El. ii. p. 356.

Var. Corpore toto nigro.

Sapporo.

This species ranges from North-eastern Europe to Manchuria, offering on the Amur some variations of colour from the European type-form; but, as far as I am aware, no examples entirely black have been found on continental Asia.

\section{Leptura (Stendra) addmbrata, n. sp.}

Elongata, nigro-fusca, pube fulvo-sericea dense vestita, elytris utrinque plaga indistincta humerali, macula apicali, fasciisque angustis obliquis duabus (altera ante, altera post medium) fulvotestaceis pube obscuratis; femoribus anticis abdominisque marginibus fulvis; antennis tenuibus, articulis apicalibus fulvis; thorace elongato-campanuliformi, lateribus fere rectis, angulis posticis valde elongatis ; elytris basi latis, apice oblique sinuatotruncatis, angulo exteriori longe producto, subtiliter discrete punctulatis. Long. 17 millim. ㅇ․

Tukio; one example.

A species remarkable for the breadth of the elytra at the base, whence they are rapidly and straightly narrowed to the apex, and the dense, not closely adpressed, pile which obscures the yellow markings. The antennis are unusually slender, more so than in $L$. obliterata.

\section{Leptura (Stendra) NympHoLA, n. sp.}

Minor, gracilis, nigra, subtus argenteo-sericea ; elytris flavescenti-fuscis fulvo-hirtis, vitta interrupta marginali lineolisque indistinctis discoidalibus (versus basin) nigris ; antennis ( $\sigma^{*}$ corpore multo longioribus) versus apicem paullulum crassioribus nigris, articulis $9-10$ octavoque apice albis; capite mox pone oculos constricto, grosse discrete punctato ; thorace gracile campanuliformi, antice sulcato-constricto, basi vix depresso, angulis posticis parum productis, dorso discrete subtiliter punctato, linea dorsali lævi ; elytris apice oblique truncatis, discrete punctulatis; pedibus nigris, quatuor anticis plus minusve testaceis. Long. 9-12 millim.

Var. Pallidior; antennis articulis $4-8$ et $11^{\text {mo }}$ basi Havis, elytris fulvescenti-flavis, vitta marginali nigra latiori (maculas 
duas flavas includenti), lineolis discoidalibus nullis; abdomine testaceo-rufo.

Chiuzenji; Niohozan; Wada-toge. The var. Wada-toge.

Strancalomorpha fenescens, n. sp.

A S. tenui (Blessig) differt thorace angulis posticis acutis, antennis nigris, etc. Sublinearis, nigra obscura, pube adpressa argentea (subtus dense) vestita, elytris olivaceo-æneis vel chalybeis subuitidis; genis post oculos sat prolongatis angulatis, capite toto creberrime punctato, linea mediana usque ad collum impressa; thorace campanuliformi, antice sulcato-constricto, postice modice depresso, angulis paullulum productis, dorso creberrime punctulato linea dorsali postica lævi; elytris crebre ruguloso-punetatis, apice vix oblique, subrecte truncatis. Segmento ultimo ventrale $\sigma$ apice rotundato; $q$ latiori, medio sinuato. Long. 11-12 millim. of $q$.

Chiuzenji; Niohozan; Wada-togé.

Apparently very closely allied to $\boldsymbol{\$}$. tenuis (Blessig), but differing in the concolorous antennæ, the denser punctuation of the elytra (in S. tenuis "ziemlich stark aber nicht sehr dicht punktirt"); it is also less linear in form, judging from the expressions used in the description of $S$. tenuis.

The genus Strangalomorpha, proposed by Blessig (Horæ Soc. Ent. Ross. ix. p. 253), differs from the subgenus Stenura in the form of the elytra, which are less narrowed behind and are depressed along the suture. I do not see the difference in the position of the base of the antennm mentioned by Blessig. The antenno are more slender than in Stenura, in both sexes being longer than the body.

Eustrangalis, mov. gen.

Lepture ( $($ Stenura) affinis: differt thorace antice et postice sulcato-constricto medioque utrinque tuberculato. Corpus valde elongatum, postice attenuatum, subglabrum, nitidum. Caput ante oculos sat elongatum quadratum, post oculos subito angustatum. Oculi subtiliter granulati. Antennæ ad oculorum marginem anticam insertæ, sat robuste filiformes, versus apicem subincrassatæ. Thorax subconicus, antice et postice trausversim profunde sulcatus, lateribus utrinque medio tuberculo valido, conico, angulis posticis haud productis. Elytra basi lati, humeris fere acuta, parum convexa, apud suturam usque ad LINN. JOURN.-ZOOLOGY, VOL. XVIII. 
apicem concava fere sulcata, apice valde oblique et sinuatim truncata, angulo suturali sat elongato acuto, exteriori longe producto. Pedes postici relative parum elongati. Coxæ anticæ et sterna normalia. Ventris segmentum apicale in utroque sexu apice paullo sinuatum, ot haud medio concavum.

Eustrangalis distenroides, n. sp. (Plate I. fig. 4.)

Nitida, fulva, vertice thoracis macula utrinque discoidali, elytrorumque utrinque vitta $a b$ humero usque ad apicem, nigris; antennis nigris; tarsis tibiisque posticis apice infuscatis. Capite punctato fere glabro; thorace punctulato, sulcis fundo lævibus, disco fulтo-aureo pubescenti; elytris sat crebre punctulatis, pilis fulvo-aureis incumbentibus sat sparsim restitis; corpore subtus fere glabro nitido; abdominis segmento terminali nigro. Long. 15-20 millim. of 우.

Nikko; Sapporo.

Strangalia Dulcis, n. sp.

Valde elongata, gracilis, sericeo-opaca, nigra, thorace sanguineo; scutello dense aureo-pubescenti, elytris humeris et apice rufescentibus.

Variat: 1. Elytris castaneo-rufis. 2. Idem, thoraceque nigro.

o. Segmentum apicale ventrale medio longitudinaliter concavum, lateralibus modice elevatis.

ㅇ. Segmentum apicale parum concavum, lateribus haud elevatis.

Long. 15 inillim. of 오.

Wada-togé; Yuyama, in Higo.

Of very elongate sublinear form, minutely and closely punctured, with fine incumbent pilosity and the surface almost opaque. The muzzle is moderately elongated and quadrate, the antennæ set a little behind the front margin of the eyes, and the head narrowed immediately behind the latter, a minute portion only of the cheeks being visible behind the eye. The thorax is narrow; widened from apex to base, the middle of the sides feebly dilated, the hind angles produced, the anterior sulcus well pronounced, but no depression across the middle of the base. The elytra are relatively narrow at the base, the apex very obliquely truncated, the surface without visible depression near the suture. The legs are long and slender, the hind pair remarkably long.

The species is intermediate between Stenura and Strangalia; the groove or concavity along the apical half of the last ventral 
segment in the $\delta$ is, however, sufficiently marked to bring it within the definition of the latter genus.

Stranatisa conmacra, n. sp.

Angusta, elytris abbreviatis et postice valde angustatis; nigra, subtus cinereo-pubescens, elytris testaceo-fulvis lateribus (suturaque interdum) nigris ; antennis pedibusque flavo-testaceis, illis articulis apice fuscis, $\nabla \in l$ fuscis basi flavis, femoribus posticis apice tibiis tarsisque nigris. Capite crebre punctulato post oculos cito rotuudato-angustato ; thorace elongato, basi modice dilatato, angulis parum productis, punctulato grieeo-pubescenti (variat linea dorsali maculaque laterali fulvis); elytris sat sparse punctatis, apice obtuso truucatis. o Segmento apicali veutrali elongato, apice late truncato, medio concavo lateribus postice elevatis. Elytris multo abbreviatis, segmentum antepenultimum vix transcendentibus. Long. 10-11 millim. ơ 오.

Kashivagi; Niohozau and Wada-togé.

Resembles the Rhinotraginæ and many species of Ophistomis in the form of the elytra, strougly narrowed from before the middle, slightly dehiscent at the apex and abbreviated-peculiarities more pronounced in the $\delta$ than the $q$, in which latter sex they leave only the pygidium uncovered, whilst in the of they reach barcly beyond the antepenultimate segment, and are also depressed along the suture.

Variable in colours: the abdomen is either wholly black or black and reddish testaceous; the lateral black vitta of the elytra emits generally two short branches near the base, but these are sometimes wanting.

Strangalia Regalis, n. sp.

Magna, robusta, subtiliter discrete punctulata, deñse suberecte breviter pilosa, vix nitida, subtus aureo-pubescens; antennis brevibus, robustis ( $\sigma$ corporis dimidium parum excedentibus). Thorace campanuliformi, ante mediuin subangulato, post medium longe sinuato, angulis posticis valde productis, antice sulcatoconstricto, medio basi curvatim sulcata; elytris convexis, valde elongatis, basi modice latis, apice transversim late sinuato-truncatis utrinque bispinosis.

ð. Segmentum ultimum ventrale valde concavum, lateribus elevatissimis, dilatatis. Nigra, elytris utrinque maculis parvis prope suturam quatuor in loco fasciarum sitis, prima prope basin, 
secunda ante, tertia post, medium, quarta ante apicem. Pedes 4 anteriores plus minusve ruf.

. Segmentum ultimum ventrale elongato-triangulare, apice emarginatum. Fulvo-aurantiaca; thorace antice et postice nigro-marginato, elytris fasciis quatuor nigris; vel nigra, elytria nigris, fasciis (interdum interruptis) quatuor fulvis, pedibus antennisque plus minusve nigricantibus.

Long. 26-30 millim. of 9.

Sapporo; Iga, on birch stumps.

\section{PrrRhon, nov. gen.}

Corpus elongato-oblongum, parum convexum. Caput sicut in Lepturis veris, ante oculos modice elongatum quadratum; genis post oculos sat elongatis angulatis, collo constricto. Palpi apice cylindrici. Oculi subtiliter granulati. Antennæ corpore multo breviores, filiformes, robustæ, articulis 3-4 conjunctis quam $5^{\mathrm{m}}$ haud longioribus. Thorax relative parvus, subcampanuliformis, lateribus fere rectis, angulis posticis acutis parum productis, antice transversim sulcatus postice depressus. Elytra rectilatera, apice late rotundata. Pedes graciles, femora paullulum clavata. Coxæ anticæ tarsique postici sicut in Lepturis.

A distinct genus of the Lepturina group, differing from other genera, except Pyrotrichus (Leconte), in the great abbreviation of the third and fourth antenual joints, and frum that genus in the unarmed thorax.

Prrrhona laticolor, 11. sp. (Plate I. fig. 8.)

Sanguinea, subopaca, dense erecte pubescens, subtus antennis pedibusque (tarsis rufescentibus) nigris, Capite et thorace creberrime punctulatis, illo linea mediana subtili impressa áb epistomate usque ad collum; elytris minus crebre punctatis. Long. 13 millim.

Yuyama.

\section{Corknrys, nov. gen.}

Gen. Pyrocalymma (Thoms.) affinis. Corpus sublineare, supra pube læte sericea, diverse adpressa, vestitum. Caput ante oculos parum elongatum, latum ; genis post oculos elongatis, latis, tumidis, collo subito maxime constricto. Oculi subtiliter granulati. Antennæ dimidio corporis parum longiores, intra oculos insertæ, robusta, $\delta$ articulis $1-5$, 9 1-8 dense hirsutis, 3- 0 longitudine aqualibus, 6-11 of cylindricis, 9-11 $q$ oblongis. Thorax relative 
parvus, inermis, subcylindricus, postice dilatatus, angulis posticis subproductis sed apice obtusis, dorso convexus, antice et postice transversim sulcato-depressus. Elytra elongata, oblongo-linearia, basi recta, apice rotundata, dorso pluricostata. Pedes haud elongati, femora subclavata, tarsi breves, posteriorum articulo primo 2-3 conjunctis parum longiori. Prosternum inter coxas conspicuum sed salde angustum, marginatum. Coxæ sicut in Lepturis elongatæ, exsertæ. Mesosterui acetabula extus late aperta. Metasternum haud convexum; episternum postice attenuatum.

Allied to the Himalayan genus Pyrocalymma, and differing from it only in the form and clothing of the antennal joints, those in Pyrocalymma ( $q$ ) being broadly triangular, prolonged at their inner apical angles, and destitute of long hairs. Both gevera agree in the margined prosternum. The antenno in Corennys much resemble those of Eroschema; but they are not essentially different from the same organs in Euryptera.

Corfnists sericata, n. sp. (Plate I. fig. 2.)

Nigra, supra creberrime punctulata, pilis longis sericeis incumbentibus fulvis, purpureis vel sanguineis dense vestita, subtus et in pedibus nigra nitida, antennis nigris ; genis tumidis post oculos glabris, a vertice linea impressa separatis.

Long. $12 \frac{1}{3}-17$ millim. of $q$.

Nanai ; Chiuzenji ; Ontaki, in flowers of Fiburnum.

Nectidalus solida, n. sp.

․ N. majori quoad colores similis, sed major, pracipue latior, thorace baud cylindrico, postico dilatato, etc. Robusta, capite thoraceque nigris supra politis, elytris castaneo-rutis, antennis pedibusque fulvo-rufis, illis versus apicem infuscatis, femorum posticorum clava supra nigra, abdomine fulvo-rufo apice fusco; capite ante oculos brevissimo et latissimo, crebre punctulato; thorace erecte piloso subtilissime punctulato; elytris basi sparsius, apice crebrius et subtilius, rugoso-punctatis, apice pubescentibus; alis fulvo-hyalinis. Long. 30 millim. $q$.

Chiuzenji.

Nectodits ebenisa, n. sp.

Toto nigra, nitida. Capite sat crebre vertice confluenter punctato; thorace vix cylindrico, basi paullo latiori, ibi et lateribus crebre punctato, disco lævi, versus apicem profunde sulcato- 
constricto; elytris æqualiter sat grosse punctatis, erecte breviter pilosis nec sericeo-pubescentibus; alis nigro-hyalinis.

Long. 22 millim. $d$ o.

Yezo, at Yunsai.

Necydalis pennata, Lewis, Ann. \& Mag. N. H. ser. 5, iv. p. 464 .

Nikko; also in Yezo.

Thmantus variegatus, Bates.

Described originally from a single example taken at Nagasaki; since taken in some abundance by Mr. Lewis in $\mathrm{Y} e z o$.

Aromia ambrostaca, Steven, Mem. MIosc. ii. p. 40.

Hakodate $(M r . O t a)$. One example, closely resembling specimens from Asia Minor, differing only in being somewhat smaller and apparently more slender.

\section{Chloridoivm thatiodes, n. sp.}

Aromice moschatce quoad colores simile, sed antennis et pedibus valde elongatis, femoribus 4 posterioribus longis parum incrassatis. Elongatum, postice parum angustatum, planatum, fere glabrum vix nitidum; supra saturate viride (thorace subcyanco), subtus viridi-æneum tenuiter auro-sericeum, antennis pedibusque subriolaceis, Capite et thorace subgrosse intricato-rugulosis, tuberculis antenniferis oblique conicis nec spinosis; elytris subtiliter intricato-rugulosis; tibiis pcsticis compressis sublinearibus; scapo grosse punctato, antice sulcato, apice dentifero. Long. 27-32 millim. of $q$.

Sapporo; Kobe.

A typical Chloridolum, according to the definition of the genus by its founder, and allied to C. alcmene (Thoms.) and C. nympha (White). The surface of the thorax and the vertex differs from that of the allied species in being coarsely and distinctly vermiculate rugose, with the transverse rugæ near the apex irregular. The antennx in the $\delta$ are about twice the length of the body. The hindmost tarsi are much narrower and longer than in Aromia moschata.

Chelidonidu quadricolie, n. sp.

A Ch.argentato (Dalm.) differt corpore magis depresso, antennis articulis $7^{\circ}-10^{\mathrm{m}}$ apice extus productis, sed haud spinosis, thorace ante spinam rectangulato, etc. Valdo elongatum sat depressum, 
subopacum, læte æneo-viride, subtus splendidum, pectore aureopubescenti, antennis pedibusque violaceis; scapo haud sulcato, apiceque obtuso, tuberibus antenniferis sat acutis; collo et thorace toto grosse scabroso-punctatis, hoc transverso, basi et apice sulcato, lateribus mox pone sulcum dilatatis, margine augulato, spina mediana magna valida ; elytris creberrime ruguloso-punctatis subglabris, pube fulva parce vestitis, obsolete bicostulatis.

Antennæ breves, in utroque sexu corpore multo breviores, articulis $7^{\circ}-11^{\mathrm{m}}$ apice extus productis acutis. Long. 22-27 millim. oㅇ.

Nara; Junsai ; Sapporo; Tokio.

The thorax is broader and anteriorly much more angulated, and the antecual joints less produced at their apex (not spiniferous) than in any described species of Chelidonium; but the species fits better in this genus than in any other of the Callichrominæ group. The middle femora, as iu the typical species, are short and strongly clavate.

Callichroma japonica (C. japonicum), Harold, Stett. ent. Zeit. 1879 , p. 335.

Japan (Hilgendorf).

Harold does not describe the antennæe or the form of the middle femora.

Rosaita Batest, Harold, Berl.ent. Zeitschr. 1877, p. 360.

Yezo. Mr. Lewis took it abundantly in August and early September on the trunks of large standing beech-trees which had been stripped of their bark. One example taken at Buno near Nikko, August 30, 1881.

Sy MPIEZocera JapontCa, Bates.

Yokohama; at dusk, March 26, 1880, running over decayed Cryptomerias.

It is the first Longicorn to appear in spring.

Rhopalopus signaticoluts (Solsky), Blessig, Hore Ent. Soc. Ross. ix. p. 177.

Sapporo. Recorded by Blessig from Suifun, E. Siberia.

Semanotes ChLorizans, Solsky, Hore Soc. Ent. Ross. vii. p. 384.

Sapporo. Also on the Upper Amur. 
Phymatodes albicinctcs, Bates, Ann. \& Mag. N. H. ser. 4, xii. p. 198 (1873).-Callidium albofasciatum, Motschulsky, Bull. Mosc. 1866*, i. p. 174; Kraatz, Deutsche ent. Zeitschr. 1879, p. 88.

Motschulsky's name has the priority over mine for this species, unless it be considered invalidated by its prior use by Bland for a North-American species (Proc. Ent. Soc. Phil. i. 1862, p. 274).

Pinmarodes Manki, Kraatz, Deutsche ent. Zeitschr. 1879, p. 88 (Callidium).-Callidium alni, Linn.? Blessig, Hork Soc. Ent. Ross. ix. p. 182.

Chiuzenji ; Oyayama.

Recorded by Blessig from the Middle Amur. Mr. Lewis's examples agree well with Blessig's description with regard to their differences from Callidium alni, except that the underside is not wholly pale reddish, the prosternum and abdomen being piceous. The species is very much larger than $C$. Alni, varying from 7-10 millim.

Plagionotus pulcher, Blessig, Horce Soc. Ent. Ross. ix. p. 184, t. viii. fig. 2.-Clytus lignatorum, Thieme, Berl. ent. Zeitschr. 1861, p. 100.

Junsai. Does not differ from the East-Siberian insect, which occurs on the Amur, in the Bureja Mountains, and on the coast at Port May.

Crytanthes aracilipes, Falderman, Mém. Acad. Pétrop. ii. 1835, p. 458 (Clytus); Kraatz, Deutsche ent. Zeitschr. 1879, p. 91 .

Fukushima. Widely distributed in Eastern Siberia, from the Altai to the Amur.

Cutiantuds iatifasciatus, Fischer, Bull. Mosc. iv. p. 439.

Sapporo.

One example, referred to this widely distributed East-Siberian species. It differs somewhat from a Manchurian specimen with which I have compared it, the oblique subbasal fascia curving sharply forward and joining the subbasal discoidal spot.

Chitanthus miseluug, n. sp.

C. plebejo proxime affinis. Minor, gracilior, niger, thorace cinereo-pubescenti, basi utrinque albo marginata; scutello nigro;

* Kraatz gives the date erroneously as 1861. 
elytris fascia a scutelli apice per suturam usque prope marginem exteriorem curvata (macula axillari nulla), fascia subrecta post medium (apud suturam antice dilatata) apiceque, cinereis; antennis, tibiis tarsisque testaceo-rutis; pectore ventrisque basi albis. Long. $7 \frac{1}{2}$ millim.

Yokohama.

Cliftanthus xeniscos, n. sp.

C. gracilipedi quoad signaturas sat similis, sed differt capite (cuin oculis) thoracis medio latiori. Angustus, sublinearis, cinerascenti-niger, scutello albo; elytris vittula obliqua longe post scutellum, maculis versus humeros duabus, fascia lata postmediana apiceque, cinereis; sternis ventreque partim albis; antennis et tarsis fulvescentibus; pedibus elongatis, gracilibus; tuberibus antenniferis appruximatis sat elevatis. Long. $7 \frac{1}{2}$ millim.

Hakodate; Sapporo.

Clytanthus (?) acotivitis, Kraatz, Deutsche ent. Zeitschr. 1879, p. 111, t. 1. f. 1.

R. Amur. According to Kratz, taken by Von Hilgendorf also in Japan.

Mr. Lewis's examples form a constant, though slight, variety as follows :-

Var. C. inscriptus. Thorax indistincte fusco-trilineatus nec maculatus; elytrorum fasciæ obliquæ apud marginem dilatatæ nec acute antrorsum reflectæ, macula nigra transversa ante apicem.

Chiuzenji and Oyayama; rare.

Kraatz places the species doubtfully in the genus or section Xylotrechus. It wants, however, the essential character of carinated centre of forehead peculiar to that generic division of Clytinæ. The long clavate femora and cristated longitudinal ridge of the thorax separate it from Clytanthus and bring it near to Clytosaurus ; it differs from the latter by its long cylindrical thorax, vertical forehead, and other characters, and belongs probably to a distinct group allied to Clytosaurus.

Demonax transilis, Il. sp.

Antennarum articulo quarto apice intus breviter spinoso. Gracillimus, cinerascenti-niger, thorace anguste elongato-ovato (mediv capite cum oculis haud latiori) cinereo-pubescenti maculis 
duabus disci nigris; elytris (basi ramulum utrinque ante humerum emittenti) vitta longe post scutellum obliqua (extus recurva et interdum ramulum basis attingenti), fascia lata pone medium (apud suturam antice valde dilatata) apiceque late, cinereis ; tuberibus antenniferis conspicue elevatis ; oculis prominentibus; ely tris apice late flexuoso-truncatis, angulis breviter spinosis; antennis ot corpore haud longioribus; pedibus gracilibus. Long. 9-10 millim.

Suyama; Nikko; Yokohama.

The short but distinct spine at the apex of the fourth antennal joint brings this species within the definition of the tropical Asiatic genus Demonax; but the spine in Demonax is generally of great length and repeated on the third joint.

Clytus metents, n. sp.

C. rhamni (Linn.) paullo gracilior, nigerrimus, elytris subnitidis, macula humerali, fascia arietina, altera post medium paullulum obliqua, scutelloque albis ; sternis singulis ventrisque segmentis 1-3 utrinque macula laterali triangulari alba. Capite, pedibus antenuisque fere sicut in C. rhamni (sed nigris), thorace longiori, oblongo-ovato multo miuus dense punctulato, cum elytris longe sed sparsim griseo-hirto et suberecte breviter nigrosetoso; elytris postice haud attenuatis, apice valde flexuosotruneat is, angulis breviter spiniferis. Long. 81-11 millim.

Junsai.

Allied to C. arietis and $C$. rhamni, but the thorax more elongate than either, the thorix without coloured margins, and the coluur of the whole insect deep black, except the scutellum, elytral markings, and spots on the underside, which are pure white.

Chrives auripilis, n. sp.

C. arieti (Linn.) longicr thoraceque relative multo magis elongato. Flavo-pilosus, thorace antice maculis 5 nigris (una mediana furcata), duabus utrinque lateralibus linearibus; ely tris pilis longis, densis, adpressis, auro-sericeis vestitis, signaturis nigris nudis opacis, viz. annulo ovali utrinque basali, fascia valde obliqua mediana (ad marginem dilatata et retrocurvata), fascia recta ante apicem, marginibusque lateralibus (post fasciam ante-apicalem) dilatata sed apicem haud attingenti. Capite sicut in $C$. arieti, sed erecte piloso; antennis dimidio corporis haud longioribus, at robustis ; thorace elongato anguste orato, postice magis quam 
antice angustato; elytris obtuse truncatis ; pedibus nigris, femoribus gradatim incrassatis, posticis elytris multo longioribus. Tıng. 12 millim. $d \hat{l}$

Sapporo.

Remarkable for the dense golden-yellow pile of the elytra, which is laid partly transversely and partly longitudinally.

Xylotrechus chinensis, Chevrolat, Rev. Zool. 1842, p. 416.

South and Central Japan; also Yezo. China.

"Feeds in the larva state in pollard mulberry-trees, planted for silkworms. In August the imago sits on the upper surface of a leaf or walks about with a jerky gait, after the manner of a hornet, which it also much resembles in colour." (Lewis.)

\section{Xylotrechus emaciates, n. $\mathrm{np}$.}

Angustus, sublinearis ; fronte subobsclete bicarinata ; thorace valde convexo qiadrato-ovato, medio haud dilatato nec basi constricto, elytris apice flexuoso-truncatis, angulo exteriori spmoso; pedibus in hoc genere gracilibus. Niger, fronte albo-bifasciata; thorace creberrime confluenter punctulato, linea dorsali cristata, marginibus antico et postico fasciaque mediana, albis; elytris nigris, basi testaceis, fascin parum obliqua subbasali, altera valde obliqua ante medium (ad suturam antice prolongata sed fasciam anteriorem haud attingenti), fascia recta ante apicem, flavis, apico late cinereis; antennis pedibusque piceo-rufis; ventre flavoannulato. Long. 8 millim. $\%$ ?

Kurigahara.

Not a typical Xylotrechus, though better placed here than in Clytus, the forehead being rounded aud having the rudiments of carins, and the thorax, though wanting the characteristic outline of $X$ ylotrechus, having a roughened raised dorsal line.

\section{Xylotrechus clarras, n. sp.}

$X$. ibici (Gebler) quam proxime affinis, differt tantum elytrorum sutura inter fascias secundam et terliam nigra, inter tertiam et apicem flava. Niger, thorace antice et pustice flaro marginato, elytris fascia secunda postice sinuata, tertia plecumque per suturam cum fascia apicali conjuncta ; antennis pedibusque fulvorufis, femoribus nigro-fuscis ; corpore subtus griseo-pubescenti, macula apud episterni metathoracis apicem, margiuibusque an- 
gustis ventris segmentorum, flavis ; elytris apice suboblique truncatis, angulo exteriori vix producto. Long. 12-15 millim.

Junsai.

Agrees with $X$ ibex (Gebler) in the points in which it differs from the European $X$. antilope, but differs in there being no trace, in the numerous specimens exanined, of yellow sutural margin between the 2nd and 3rd fasciæ of the elytra, but, on the other hand, distinct traces of a similar margin between the 3rd fascia and the yellow apex. The posterior margin of the thorax is yellow, interrupted sometimes in the middle, and sometimes also on each flank, but never forming two distinct subtriangular spots ; the yellow spot on the mesothoracic episterna is wanting, as in $X$. $i b e x$, and the $2 \mathrm{nd}$ fascia is siuuated behind as in that species; it is also continued anteriorly along the lateral margin, which under the shoulders is testaceous, as is also the baso near the scutellum.

Xrlotrechids albifilis, n. $\mathrm{sp}$.

X. hirco (Gebler, = decolor, Thieme) quoad colores simillimus, sed multo major, valde elongatus, thorace absque lineolis albis ete. Niger, opacus, elytris pallide fuscis vel lividis nitidis, vitta lata marginali bis-interrupta nigra, fasciisque tenuissimis et obliquissimis duabus, guttula subhumerali et macula trigona apicali, cinereoalbis (fascia prima a margine usque $j_{1}$ ope suturam curvata, deinde usque ad scutellum oblique continuata, secunda post medium a sutura usque ad marginem oblique ducta); fronte medio bicarinata, carinis postice conjunctis et in carinam unicam continuatis, narginibusque acute carinatis; thorace medio parum dilatato, dorso postice convexo aspere rugoso, basi prope angulos utrinque macula cinerea; elytris postice vix angustatis, apice recte truncatis angulo exteriori spinoso, dorso subtilissime punctulato breviter incumbenti-setoso nitido, utrinque obsolete bicostulato; corpore subtus nigro sat nitido, breviter griseo-pubescenti, metathoracis episterno apice macula magna flava, metasterno ventrisque segmentis $1-3$ apice interrupte flavo-marginatis. Antencr ( $\delta$ ) dimidio corporis paullo longiores filiformes; pedes robusti, femora valide incrassata; tarsi postici articulo primo longissimo, 2-4 brevissimis. Long. 16-20 millim.

Junsai : Usui-togé.

Var. Signaturis cinereis paullo latioribus, suturaque a scutello usque fasciam secundam late cinereo marginata. R. Amur. 
The peculiar colour and thread-like markings of the elytra are nearly the same as in $X$. hircus, Gebl., with the exception that $X$. albifilis has a large, triangular, grey-white spot at the sutural apex. But the two species differ very greatly in many points of structure: in $X$. hircus the frontal carinæ are divergent behind, and there is no single carina in continuation aloug the vertex; the antennæ are formed of shorter and rather more triangular joints instead of being filiform; the thorax is very broadly dilated and rounded ("globosus," as Gebler describes it), in $\boldsymbol{X}$. albifilis it is oblong-ovate, and the elytra are rounded at the apices and of less elongated outline in shape.

The Amur specimen, which differs a little in elytral markings from Mr. Lewis's series from Japan, was obtained from the same collection, made on the Amur, which contained examples of $X$. hireus. The species appears not to bave been described by any of the numerous writers on East-Siberian Coleoptera.

Xylotrechus rufiuds, $n$. sp.

$X$. pyrrhodero (Bates) simillimus. Brevior, niger opacus, thorace (margine antico nigro excepto) supra sanguineo, elytris basi, fascia subrecta subbasali (suturaque inter fasciam et scutellum), fascia ante-apicali (vittaque marginali inter fasciam et apicem) cinereis (interdum testaceo-cinereis); subtus nigro, cinereo-pubescenti, metathoracis episternis, apice ventrisque segmentis 1-3 postice densius cinereis; fronte medio sex-carinata; thorace subgloboso, dorso grosse intricato-ruguloso ; elytris curvatim modice angustatis, apice subrecte-truncatis angulis acutis, adpresso-pilosis. Antennæ in utroque sexu filiformes nec apice incrassatæ. Long. 9-10 millim. of $q$.

\section{Junsai.}

In $X$. pyrrhoderus the middle frontal carinæ are obsolete and undistinguishable, but the lateral carinæ very acute; the antennse are greatly thickened (excessively so in $q$ ) after the 4th joint; the thorax finely intricate rugulose-punctate and red beneath as well as above; the elytra bave no part of the suture grey, and want the apical lateral grey streak; lastly, the body beneath is diferently clothed with grey pile, the middle being shining black, and one fascia only being present across the ventral segment.

Xrlotrechus Grayi, White.

Add to the localities formerly recorded, Yezo. 
Bractirchtutus singuraeis, Kraatz, Deutsche ent. Zeitschr. 1879 , p. 107 , t. 1 . fig. 6 .

Between Hakone and Syama, in flowers of Deutzia.

Agrees with Krantz's description, with the unimportant exception that the posterior fascia of the elytra is bright yellow instead of "testaceous" like the anterior band, and that the base of the elytra is not red, but a light purplish brown. The genus is closeiy allied to $X_{y}$ lotrechus, Mr. Lewis's example showing the rudiments of frontal carinæ.

Afaglyptus Niponensts, $n$. sp.

A. gibboso quoad formam similis, sed differt coloribus lætioribus, elytris apice transversim sinuato-truncatis, angulo exteriori longe spinoso, etc. Postice attenuatus, niger, elytris dimidio basali rufo, antice fascia lata utrinque purpureo-nigra cinereo-marginata, a sutura curvation et oblique versus marginem (quod non attigenti) ducta, medio macula magna communi cinerea; posthac, fascia lata antice bidentata nigra, apice late cæruleo-griseis. Capite et thorace creberrime ruguloso-punctulatis, hoc postice gibboso subenmpresso, basi constricto; elytris a basi usque ad apirem recte angustatis, apice transversim sinuato-truncatis, angulo suturali breviter, externo longissime, spinoso, basi rectis humeris subacutis, crista utrinque basali valde elevata, carinula submarginali postice acuta usque ad spinam continuata. Antennæ, articulo tertio sequente duplo longiori, apice intus quam in $A$. gibloso brevins spinoso, articulis $4^{\circ}-6^{\mathrm{m}}$ apice brevissime spinosis. Long. 7-9 millim.

Miyanoshila; Kiga; Oyayama; Nikko.

Paraclitus, nov, gen.

Gen. Anaglypto affine; differt antennarum articulis 3-5 subæqualibus, tertio apice in utroque sexu inermi.

This new generic division is necessary for the reception of a species which differs from Anaglyptus and Cyrtophorus by the absence of all trace of spine, in either sex, froin the Brd antennal joint. In the style of marking and general form it differs also much from the genera mentioned and all other Clytinæ. Clytus caucasicus, Motschulsky, referred by modern writers to the genus Anaglyptus or to Cyrtophorus, belongs to Paraclytus.

Paraclxtus excul,tus, n. sp. (Plate I. fig. 11.)

Elongatus, linearis, niger, cano vel griseo tomentosus, thorace 
supra plagis duabus (interdum in 4 divisis) nigris, elytris nigris margine laterali et medio basis testaceis ; vittula curta obliqua ab humero versus discum, vitta valde obliqua a sutura usque marginem, ante medium, macula transversa mediana juxta suturam, fascia recta ante apicem, sutura a scutello usque ad hanc fasciam et apice late, cinereis (fasciis etc. prope basin plus minusve testaceis); antennis (corpore longioribus) pedibusque nigris, subtiliter griseo-pubescentibus; thorace subcylindrico, medio utrinque subangulato basi constricto; ely tris apice declivibus juxta suturam brevitersinuato-truncatis, angulo exteriori modice producto, cristis basajibus obtusis parum elevatis; humeris vix rectis. Iong. 11-15 millim.

Sparingly throughout Japan.

The white markings and the clothing of the underside consist in fine and compact adpressed pile; the head and margins of pronotum have a similar but rather coarser pile. The rich deep black parts of the elytra have a black pile, generally partly abraded, and exposing a close and strong punctuation of the integument.

Aglaophis colobothfoides, n. sp. (Plate I. fig. 12.)

Facies gen. Colobothece. Nigra, antennis articulis (a secundo) basi griseo-rufis, femoribus pedunculo rufo, elytris ultra medium fascia recta lata (marginibus dentatis) nigra, apice late civereis, catera superficie rufo-castaneo nigro varia, fasciis irregularibus undulatis et intermixtis cinereis ; capite griseo-birto; thorace fere sicut in Anaglypto mystico, sed magis convexo, creberrime alveolato-punctato; elytris lineari-oblongis, versus apicem attenuatis apice anguste sinuato-truncatis angulo externo longe et acute producto, lateribus altis et verticalibus, prope humeros prominentes subcarinatis; pedibus sicut in $A$. mystico, femoribus abruptius clavatis. Loug. 14 millim. $q$ ?

Sapporo.

The head and thorax are nearly the same as in Anaglyptus mysticus (Linn.), but the elytra more nearly approach, in form and colours, certain species of Colobothea. I refer the species to the Indian genus Aglaophis, notwitbstanding the absence of the peculiar double convexity of the thorax in that genus, this character being distinctly pronounced, judging from an undescribed species which I have examined, in the $\delta$ only. The third joint of the antennæ is much longer than the fourth and unarmed, the 
lateral carina of the elytra near the angular shoulder is not sharply pronounced as in the typical Aglaophis, but obtuse; the basal crests are elevated, compressed, and clothed with black hairs.

Punpurtcenus arectabilis, Motsch.

Syn. P. nigrohirtus; Lewis.

Kobe, north to Sapporo.

Fam. LA M I I D $\mathbb{E}$.

Phuxctidola, nov. gen.

Gen. Deucalioni et Dorcadidae affine: differt thorucis spina laterali plurituberculata etc. Elongato-ovata, convexa, subglabra ; caput inter antennas latum, parum concavum. Palpi articulo terminali breviter ovato acuminato. Antennæ corpore longiores, scapo sicut in Deucalioni oblongo-clavato, articulo tertio cæteris multo hongiori, sed haud crassiori, $4^{\circ}-11^{\mathrm{m}}$ gradatim parum decrescentibus. Thorax quadratus, medio angulatim dilatatus ibique plurituberculatus, tuberculo centrali (in loco spinæ) majori. Elytra regulariter convexa, apice obtusa. Acetabula antica extus late angulata; intermedia aperta. Ventris processus intercoxalis latus, ogivalis. Tibiæ intermediæ medio extus vix tuberculatæ sulcisque haud conspicuis.

The species on which this genus is founded is most nearly allied to the rare Madeiran genus Deucalion, the only structural features which distinguish it from that form being the widely gaping anterior haunch-sockets and the nearly simple outer edge of the intermediate tibiæ. In general form, however, the species much more nearly resembles Parmena, from which it differs in the absence of long pubescence, the rather longer and more oblong scape (much shorter and thicker than in Dorcadida), and the broad ogival intercoxal process.

Pellyctidola metallida, n. sp. (Plate I. fig. 2.)

Cupreo- vel æneo-fusca, subnuda parum nitida, pilis fulvis curtis adpressis supra elytra maculatim vestita ; scutello dense fulvo-pubescenti; capite et thorace grosse intricato-rugosis, hoc plagis 2-3 parvis elevatis politis; ely tris sat grosse punctatis subrugosis, utrinque costis obtusis sæpe interruptis nitidis tribus. Long. 10-11 millim.

Sapporo; Nikko ; Oyayama. 
EonтHistatos BINoDosus, Waterhouse, Trans. Ent. Soc. 1881, p. 431.

Occurs from Chiuzenji north to Awomori, and also on the island of Sado, on beech-trees. Commonest in September.

Echthistatus Furciferds, n. sp.

E. gibbero (Bates) similis, sed differt elytris tuberculis parvis rotundatis nigro-nitidis conspersis, una utrinque prope scutellum multo majori. Ochraceo-fuscus, antennis pedibusque piceo-rufis, elytris sicut in $E$. gibbero, epipleuris altis verticalibus carinaque flexuosa a dorso separatis; postice subito declivibus sed declivitate multo longiori apiceque longius divergenti-spinoso. Long. 15 millim. $d$.

Hiogo, on Maigasan.

Eohthistatus grossus, n. sp.

E. gibbero proxime affinis et forsan ejus varietas ; differt elytris a basi paullo dilatatis, gibbere altiori et latiori, spinis apicalibus latioribus minusque acuminatis ; colore obscuriori, nigro-fusco. Long. 16 millim. o .

Yuyama, in damp forests in May.

In $E$. gibber the elytra are broadest at the shoulders, but in $E$. grossus at the end of the gibbosity, where the tuberculated lateral carina curve round towards the disk. The small tubercles at the base of the elytra, on each side of the scucellum, are much more numerous, about twelve, and larger, forming a linear crest.

The genus Echthistatus seems to me to belong to the true Lamiince, and not to the Dorcadionine, where Lacordaire placed it, trusting too much to the shortness of the metasternum, which led him to introduce numerous forms into the Dorcadionina subfamily which have their true affinities elsewbere. The cicatrized tip of the scape, one of the chief characteristics of the Lamiine, is strongly marked in $\boldsymbol{E}$. gibber and $\boldsymbol{E}$. grossus, more feebly so in E. binodosus, and only just perceptible in E. furciferus.

\section{-Dolophrades, nov. gen.}

Gen. incertæ sedis Monohammis minoribus haud dissimile. Parrus, anguste elongato-ovatus. Caput sicut in Dorcadida, vertice integro vix concavo, post oculos haud impresso. Palpi articulis apicalibus ovatis, breviter truncatis. Antennm ( $\delta$ ) fere sicut in Monohammo fraudatori (Bates), corporis dimidio lonLINN. JOURN.-ZOOLOGY, VOL. XVILI. 
giores, articulis 3-4 crteris paullo crassioribus; scapo subcylindrico, apice anguste cicatricoso et carinulato. Thorax quadratus, spina laterali retrorsum paullo curvata. Elytra a medio gradatim angustata, humeris subrectis, apice rotundata, supra parum convexa, postice sensim declivia, grosse sublineatim punctata. Pedes sicut in Monohammis, tibiæ intermediæ infra medium tuberculatæ. Pro- et mesosterna arcuata; metasternum paullo abbreviatum. Acetabula antica extus angulata, intermedia aperta.

Founded on a small species partaking of the characters of the two subfamilies Dorcadionina and Lamiina. The head and thorax are, relatively to the rest of the body, long, and resemble much those of Dorcadida, Deucalion, and allies; the thoracic spines, though much smaller, are similar in position to those of Lepromoris.

Dolophrades 'TERRends, n. sp. (Plate I. fig. 10.)

Fulvescenti-fuscus, subsericeo-tomentosus ; scutello ochreopubescenti; antennarum articulis 4-11 basi obscure griseis; capite et thorace passim discrete punctulatis, hoc supra inæquali ; elytris grossius, hic illic seriatim, punctatis, interstitiis subrugulosis. Long. 10 millim. $\delta$.

Hitoyoshi.

Monohammus NITENs, n. sp.

$M$. sutori etc. affinis, sed differt elytris æneo-nigris politis albomaculatis. Elongatus, $\delta$ postice vix angustatus, æneo-niger politus subtus griseo-pubescens, supra maculis albis (raro ochraceo-albis) parvis irregularibus passim conspersis, apud elytras hic illic in maculas majores confluentibus; antennis nigris concoloribus; thorace antice et postice ruguloso, disco variabili, sparse punctulato, vel scabroso, interdum sublævigato; spina laterali valida ; elytris erecte setosis, subtiliter punctato-rugulosis interdum fere lævibus, versus basin granulato-punctatis. Long. 22-27 millim. of 9 .

Niohozan, middle of August, on Abies nowly felled.

Monohammus Luxuriosus, Bates.

Yezo.

Monohamaus grandis, Waterh. Trans. Ent. Soc. 1881, p. 431.

Yezo. Chiuzenji and Sapporo, takem flying in August; dug out of Abies on Toukula-yanal in June. 
Monohammus pardalinus, n. sp.

Pro hoc genere parvus et gracilis ; antennis tenuibus, articulis 3-5 subtus sparse ciliatis tibiisque intermediis medio extus haud tuberculatis. Elongatus, fuscus, supra pallidus vel fulvo-fuscus, maculis numerosissimis rotundatis atro-fuscis, plerumque separatis conspersis, post medium in maculam utrinque majorem congestis. Capite et oculis sicut in Monohammis typicis, sed tuberibus antenniferis apice haud acutis ; antennis $\left(\sigma^{*}\right)$ corpore plusquam duplo longioribus, obscure rufis, articulis a tertio basi griseo-testaceis; thoracis spinis lateralibus conicis acutis; elytris relative valde elongatis, post medium paullulum ampliatis deinde usque ad apicem curvatim angustatis, apice singulatim rotundatis. Long. 12 millim. $\delta$.

Yuyama.

The slender antennæ and the markings give this species the appearance of an elongate Leiopus; but the perfectly margined cicatrice and the shape of the scape, the thorax, and other characters are those of Monohammus. The slightly rounded sides of the elytra are seen in several small species of true Monohammus from Assam and Siam, and the scantily ciliated basal joints of the antennæ it partakes with $\boldsymbol{M}$. Fredericus (White). The only character which may be of generic importance is the total absence of tubercle and notch preceding the sinuation of the middle tibix.

Haptohammus, nov. gen.

A Monohammo differt scapi cicatrice læviori, minus acute et integriter marginato. A Dihammo (Thoms.) differt tibiis et tarsis anticis o normalibus.

A genus proposed for a numerous series of Indo-Malayan and Australasian Monohammi which differ from the typical species by the smoother antennal scape and the less abruptly truncated and smoother cicatrice, the bordering rim of which is much less complete. The series of species is readily distinguishable from the true Monohammi by their more uniform colours and "facies." Dihammus, Thoms., an equally numerous Eastern group, presents a similar form of cicatrice, but is amply distinguished by the prolonged external apices of joints 1 and 2 of the anterior tarsi of the male, and the dentiform projection which surmounts the groove of the anterior tibir in the same sex. 
The following Japanese species belong to the genus:-H. luxuriosus, H. fraudator, $H$. sejunctus, and $H$. degener* $*$

Haplohammus fulficonnis, Pascoe, Ann. \& Mag. Nat. Hist. ser. 4 , xv. p. 64.

Japan (Whitely). Hakodate (?).

Mr. Lewis considers this as belonging either to $M$. sejunctus or $M$. fraudator (Bates). I have seen no specimens which exactly agree with Pascoe's description of the antennæ.

\section{URECHA GRISEOLA, 11. sp.}

Elongata, angusta, fusca, antenuis (scapo fusco excepto) pedibusque fulvescenti-rufis, elytris apice obtuse rotundatis, griseis, fusco maculatis, vitta mediana valde obliqua, maculaque irregulari submarginali, fuscis; thorace et elytris quam in $U$. bimaculata grossius punctatis; spina laterali thoracica angusta, acutissima paullulum hamata. Long. 9 millim. of

Kashiwagi.

Of similar elongate sublinear form to the type species $U . b i$ maculata; the antennæ also proportionately long, more than twice the length of the body. From Uracha (Monohammus) angusta, Pascoe, with which it agrees in the obtuse apices of the elytra, it differs in markings, and especially in the finer and longer thoracic spines.

URACHA BIMACULATA, Thomson.

South and Central Japan; also Yezo.

\section{Mectipippos, nov. gen.}

Gen. Goes (Leconte) simillimus, Thesto (Pascoe) affinis. Maxime elongatus, sublinearis. Caput sicut in Monohammis veris, oculis infra paullo latius quadratis; palpi tenues, apice acuminati. Antennæ ( $\delta$ \% ) corpore paullo longiores; scapo brevi, oblongo-conico, cicatrice lata grosse scabrosa integriter

* Haplohammus is closely allied to Orsidis, Pascoe, and I have hesitated to separate it; the form of the scape and its cicatrice is nearly the same iu botb, but Orsidis, at least the type species $O$. oppositus, differs from all the Haplohammi in the larger and broader lower lobe of the eyes and shorter forehead, characters which, being supported by some difference in the form of body and thoracic spines, may justify the severance of the two genera. Some of Pascoe's Orsidis, e. g. O. sobrius, are possibly true Haplohammi; O. sobrius is probably closely allied to the Mon. fulvioornis of the same author. 
marginata, articulis 3-5 subtus densissime ciliatis. Thorax relative brevis, spina laterali longissima, recta, acuta. Elytra relative longissima, apice breviter truncata, humeris rectis, subtiliter parce sublineatim punctulata, versus basin minute granulata, obsolete pluricostulata. Sterna normalia inermia. Tibiæ intermediæ extus tuberculo mediano acuto subspiniformi.

In the dense hair-fringe beneath the antennal joints 3-5 this genus resembles Thestus, from which it differs in the long thoracic spine, plaue mesosternum, and other characters. The resemblance and real affinity to the North-American genus Goes is not less striking. The short antennal scape, about one third the length of the third joint, and the long and acute tubercle of the middle tibia are features peculiar to the genus.

Mecrnippds PUbicoris, n. sp. (Plate II. fig. 12.)

Maxime elongatus, pallide fuscus, antennis pedibusque testaceorufis ; fulvo-tomentosus et brevissime erecte setosus, fusco-conspersus, fascia elytrorum mediana obliqua cinerea (interdum subobsoleta) et, pone hanc, fascia vel macula magna triangulari obseure fusca; supra toto sparsim punctulatus, punctulis versus elytrorum basin granulatis, versus apicem obsoletis, lineis longitudinalibus indistinctis elevatis; apice juxta suturam breviter sinuato-truncatis. Long. 20-26 millim.

Sapporo.

Apalima, nov. gen.

Gen. Palimnce (Pascoe) affinissimum; differt tantum thorace utrinque tuberculo valido conico, antennisque articulo septimo (ut cateris) simplici. Frons infra paullo.dilatata.

The species on which this genus is founded resembles the Palimnce in colour and markings, but differs in the thorax having large covical lateral tubercles. Its real aftinity to the Palimnce is shown in the form of the cicatrice of the scape-very large and coarsely scabrous, and limited by a carina only for one half its contour ; and also in the long middle tibiæ, on which the tubercle and groove lie nearly at the apex. The species wants the spinose centro-basal crests of the elytra, but these are not constant in Palimna, an undescribed species from the Andaman Islands exhibiting them in a very rudimentary condition. 
Apalmina liturata, n. sp.* (Plate II. fig. 5.)

Oblonga, cinereo-albo tomentosa, antennis et pedibus nigroannulatis, capite postice, maculis septem, thorace vittis quatuor (2 medianis interruptis) elytrisque maculis numerosis plerumque undulatis, nigris ; elytris oblongis, passim sparse punctatis, prope apicem angustatis, apice singulatim acuminatis vel brevissime oblique truncatis, tuberibus centro-basalibus obtusis paullo elevatis. Long. 18 millim.

All the islands, in beech-forests.

Xentcotela, nov. gen.

Gen. Xenolece (Thoms.) simillima, sed differt antennarum scapo apice anguste cicatricoso, lævi, acute et integriter marginato. Parva, subcylindrica. Oaput exsertum ; tubera antennifera elevata, divergentia; frons quadrata plana; oculi grosse granulati. Antennæ corpore duplo longiores, apicem versus tenuiores, scapo brevi, oblongo-clavato, cicatrice angustissima acute marginato, lævi; articulo $3^{\circ}$ elongato, robusto, cæteris gradatim brevioribus. Thorax cylindricus, tuberculo mediano valido, conico. Elytra cylindrica, æqualia, apice conjunctim rotundata. Pedes sat breves et tenues, tibiis anterioribus flexuosis, intermediis simplicibus. Acetabula antica extus angulata, intermedia clausa.

Founded on a small species resembling much Xenolea, but differing from that genus and its allies (Dorcasohema, Hetcomis, \&c.) in the scape being smooth, with the cicatrice narrow and sharply margined, instead of very large, oblique, and scabrous, as in the genera just named.

X Eicicotela fuscula, n. sp. (Plate II. fig. 2.)

Olivaceo-fusca, adpresso-pubescens, antennis et tarsis fulvo-

* A second and much finer species of Apalimna occurs in Northern India. It is relatively much broader and more robust, with elytra more triangular in outline and furnished with strongly bituberculated centro-basal crests. The other characters are as in $A$. liturata.-Apalrms ducalrs, n. sp. Lata, robusta, cinereo-albo tomentosa (prope scutellum et humeros fulva), antennis et pedibus nigro-annulatis, capite antice et occipite thoracisque disco maculatis, elytris fascia obliqua post medium maculisque suturalibus et apicalibus, nigris: thorace disco trituberculato, scutello bicornuto, elytris apice conjunctim rotundatis, basi latis, humeris tuberculatis antice productis, erista utrinque centro-basalis valde bituberculatis, pone seutellum et humeros grossissime punctatis, carinaque discoidali flexuosa. Long. 20-24 millim. $\sigma^{\pi} q$. North India (Buckley). 
testaceis, illarum articulis a tertio basi pallidis, capite et thorace sparsim punctulatis, elytris paullo grossius sublineatim punctulatis, interstitiis subrugulosis, atro-fusco maculatis, maculisque utrinque tribus irregularibus majoribus (subbasali, mediana et subapicali). Long. 7 millim. o .

Higo.

\section{Rhodopir INTEGRIPENAIs, n. sp.}

R. Lewisii (Bates) affinis. Elongatus, rufescenti-fuscus, fulvoochraceo adpresso-pubescens ; antennis testaceo-rufis, clava ( $d^{*}$ ) nigra, polita, articulis 4-11 apice fuscis ; elytris apice conjunctim rotundatis, fusco-guttatis, utrinque macula angulari pone medium versus marginem nigra; pedibus piceis, femoribus tibiisque basi testaceo-rufis: supra totus punctulatus, elytris paullo grossius punctatis. Long. 12 millim. ot

Wada-toge.

Differs from the other described species of this well-marked genus in the perfectly rounded apices of the elytra.

Rhорорis Lewisir, Bates.

Hiogo ; Yezo.

NANOHAMMUS, nov. gen.

Gen. Olenocampto et Xenolece affinis; differt tibiis intermediis simplicibus. Parrus, cylindricus, subglaber. Caput exsertum, occipite lato et convexo; fronte brevi, quadrata, vertice inter antennas concava, post oculos haud transverse impressa. Oculi angusti, grosse granulati, lobis inferioribus infra subacuminatis. Palpi elongati, articulo terminali præcedenti duplo longiori. Antennæ ( $q$ ?) corpore parum longiores, subnudæ; scapo gracili oblongo-conico, apice extus obsolete late cicatricoso, ex parte subtilissime marginato; articulo tertio quam scapus tertia parte longiori, quam art. quartus paullo longiori, cæteris gradatim decrescentibus. Thorax breviter cylindricus, antice et postice leviter constrictus, tuberculo laterali mediano, acutissimo. Elytra cylindrica, æqualia, crebre punctata, apice rotundata. Sterna simpliciter arcuata ; acetabula antica extus late angulata; intermedia aperta. Pedes modice elongati; tibiæ intermediæ graciles, lineares, extus omnino integræ. Tarsi sat breves et lati; ungues divaricati.

In facies resembling Monohammus, though of diminutive size. Differs from that genus and from Olenocamptus and allies, to 
which it is more nearly allied, in the perfectly straight outer edge of the intermediate tibiæ. The cicatrice of the scape is visible only in a certain light, and recognizable chiefly by its limiting margin; it is very broad, as in Xenolea.

\section{Nanohammos rufescens, n. sp. (Plate II. fig. 4.)}

Fulvo-castaneus, subnudus, thoracis linea dorsali, scutello maculisque elytrorum (ante et post medium subfasciatim congregatis) ochraceo-tomentosis; antennarum articulis 3-4 basi tibiisque pallidioribus; capite omnino discrete punctulato; thorace creberrime subconfluenter, elytris passim discrete hic illic seriatim, punctatis. Long. 7 millim.

Chiuzenji.

Scotinadges diphysis, Pascoe, Ann. \& Mag. N. H. 1871, p. 277 , t. xiii. fig. 4 .

Island of Tsu-shima (Bowring).

This species was omitted from my first enumeration of the Longicornia of Japan.

Mesosa gracilior, n. sp.

M. nebulose (Oliv.) primo intuitu similis, sed angustior, gracilis, thorace præcipue angustiori, minori lateribusque rotun. datis. Anguste oblonga, fulvescenti-fusco adpresso-pubescens, vertice et thorace nigro pluri-maculatis (nec vittatis); elytris guttis sat confertis nigris fasciaque mediana dentata cinerea nigro partim marginata; antennis nigro-fuscis, articulis basi griseis; elytris elongato-oblongis, crebrius quam in $\boldsymbol{M}$. nebulosa punctulatis. Long. 10-11 millim. $\delta$ ․

Oyayama.

Narrower and more elongated than $M$. nebulosa, the thorax especially relatively much smaller and narrower and rounded on the sides.

Mesona japontca, Bates.

S. Japan ; also Yezo.

Mesosa Hinsuta, n. sp.

Elongato-oblonga, supra dense erecte pubescens, fusco-tomentosa, griseo plagiatim varia; thoracis maculis novem (interdum indistinctis), elytrorum maculis circa 20 , quarum 4 suturalibus communibus, atro-fuscis; antennis fusco-nigris, articulis 3-11 
basi griseis, scapo griseo et fusco-piperito, art. undecimo præcedenti $\delta$ paullo, $q$ dimidio, breviori; thorace vix inæquali, lateribus leviter rotundatis, sparsim punctulato; elytris subtilius quam in $M$. nebulosa punctulatis ; pedibus griseis nigro-annulatis sicut in $M$. nebulosa. Long. 12-16 millim. of .

Kobe.

\section{Mesosa senilis, n. sp.}

M. nebulose quoad formam similis, sed paullo magis elongata, canescenti-griseo tomentosa, thoracis vittis duabus angustis (sæpe obsoletis), elytrorum vitta curvata subbumerali, macula longe post medium marginali maculisque suturalibus discoidalibusque (sæpe deficientibus) nigris. Antennis griseis, articulis 3-10 apice breviter infuscatis, $\sigma^{*}$ corpore dimidio longioribus, articulo undecimo o elongato precedenti sublongiori, $q$ præcedenti breviori; thorace sicut in $\boldsymbol{M}$. nebulosa inæquali ; scutello toto griseo; elytris sparsim punctatis, punctis nigris. Long. 11-12 millim. d 9 .

Junsai ; Oyama; Sapporo.

Varies much in the number and distinctness of the black spots and marks; the hoary laid pubescence is sometimes thin and coarse, and then seems to cover the black marks. In some examples the prevailing colour is light brownish-grey instead of light grey.

\section{Mesosa pacila, n. sp.}

Elongato-oblonga, erecte nigro-pubescens, griseo- vel ochraceogriseo tomentosa tota nigro-piperita, fascia undulata elytrorum longe post medium (suturam haud attingenti) maculisque 2-3 marginalibus prope humerum, nigris. Capite inter antennas profundius quam in $\boldsymbol{M}$. nebulosa concavo; thorace relative parvo, juxta basin angustato, dorso hauu tuberculato sed antice transversim depresso; scutello griseo, lateribus nigris; elytris punctulatis; antennis griseis, articulis omnibus apice nigris, $q$ (?) art. undecimo precedenti dimidio breviori; pedibus griseis nigromaculatis. Long. 13-17 millim.

Nikko; Junsai.

Mesosa cribrata, n. sp.

Parva, oblonga, erecte pilosa, griseo-fusca tomentosa, elytrorum fasciis duabus latis (altera recta basali, altera post mediana undulata) atrofuscis. Capite inter antennas parum concavo; thorace brevi cylindrico, supra æquali, sparsim grosse punctato; 
elytris grosse (versus basin crebre) punctatis; antennis atrofuscis, articulis 3-11 basi griseis, articulo undecimo ( $q$ ?) precedenti duplo minori; pedibus nigro-fuscis griseo variis. Long. 7 millim.

Sapporo.

\section{Mesosecta, n. gen.}

Gen. Mesose similis, sed differt antennarum scapo apice integro unguibusque subparallelis; subfam. Niphonine pertinet. Caput inter antennas triangulariter concavum, tuberibus antenniferis apice haud prominentibus. Oculi modice emarginati. Antennæ corpore fere dimidio longiores, scapo quam art. tertius multo breviori, gradatim clavato, nullomodo triquetro, creberrime punctulato, apice extus lævi, polito; art. tertio sat elongato (cum quarto et quinto) subtus ciliato, quarto paullo breviori, cæteribus gradatim decrescentibus. Thorax brevis, subcylindricus, supra æqualis. Elytra oblongo-ovata, absque cristis et tuberculis. Tibiæ intermediæ extus integræ. Tarsi articulo unguiculari elongato, parum robusto.

According to Lacordaire's classification, this genus belongs to the group or subfamily Niphonince. The species on which it is founded has, however, the closest resemblance to the Mesose, and might well be taken for $M$. gracilior. The absence of cicatrice from the scape, though its place is indicated by a smooth polished area in the else closely punctured surface, is the chief distinguishing character. The subparallel or "divergent" claws are a less conclusive mark of distinction between the two groups Mesosina and Niphonine, many species of the former having claws tending towards the "divergent" position.

Mesoselia simiola, n. sp. (Plate II. fig. 3.)

Oblongo-subovata, obscure fusca, fulvo-fusco tomentosa, nigro maculatim varia, elytris fascia post medium dentata (suturam haud attingenti) cinereo-alba ; antennarum articulis 3-11 dimidio basali testaceo; pedibus nigris griseo parce maculatis, unguibus fulvis. Long. 8 millim.

Nikko.

Resembles Mesosa gracitior and Praonetha leiopodina, and intermediate in form between the two species.

SygRa sUbFascrata, n. sp.

Elongata, postice sat convexa; elytris apice singulatim rotun- 
datis subangulatis; ochraceo-fusca, atro-fusco (præcipue pone medium) maculata, scutello fasciaque post-mediana (nec latera nec suturam attingenti) cinereis; antennis piceo-rufis, articulis 3-11 basi pallidis; thorace cylindrico, basi paullo angustato, crebre punctulato; elytris crebre, apicem versus subseriatim (ibique interstitiis subelevatis) punctulatis. Long. 11 millim.

Higo.

An elongated species, with the ely tra rather rounded from behind the middle to the apex, the latter singly triangularly produced, but not toothed or spined. The coloration is the same as that of Mesosa gracilior, Mesosella simiola, and Praonetha leiopodina.

XYLaRtopsis, nov. gen.

Gen. Atimura affinis. Corpus elongato-subcylindricum, postice angustatum, tuberculatum. Caput inter antennas vix concarum, tuberibus antenniferis parum elevatis obtusis, fronte brevi, quadrata, oculis modice emarginatis, grosse granulatis. Antennæ quam corpus vix breviores, subtus ciliatæ; scapo oblongo, articulo tertio quam scapus parum longiori et articulo quarto subæquali, 5-11 gradatim sed parum decrescentibus. Thorax cylindricus, plurituberculatus. Elytra basi thorace multo latiora, versus apicem angustata, apice depressa et producta, apice ipso truncata, dorso subseriatim tuberculata. Pedes breves, robusti; femora clavata; tibiæ intermediæ extus profunde sinuatæ.

XrLariopsis mimica, n. sp. (Plate II. fig. 7.)

Breviter sparsim setosa : capite fulvo et fusco tomentoso, occipite bipenicillato ; thorace cano-tomentoso, margine basali fuscomaculato ; scutello ochraceo linea mediana impressa ; elytris fusconigro tomentosis, fascia lata antice obliquata paullo ante apicem albo-cinerea; antennis testaceo-fulvis ; pedibus cano-tomentosis fusco-variï, tarsis rufescentibus. Long. 12 millim.

Chiuzenji ; Sapporo.

Sxdonia divaricata, n. sp.

Sublinearis, fusca, griseo adpresso-pubescens, thorace utrinque griseo-bivittato; elytris vitta discoidali arcuata indistincta subnuda lineolaque grisea utrinque post medium. Capite et thorace subcrebre punctulatis (hoc cylindrico); elytris versus apicem angustatis, apice utrinque oblique truncatis angulisque exterioribus productis divaricatis, supra apice excepto crebre punctatis, 
dorso medio longitudinaliter paullo elevato, versus suturam postice depresso tuberibus centrobasalibus obtusis; antennis et pedibus fusco-rufis, illarum articulis a tertio basi cinereis, tibiis apice tarsisque nigris. Long. 7 millim.

Higo; Yuyama.

Belongs to Lacordaire's group Estolides, and agrees with the genus Sydonia (founded on a species from Singapore) in its cylindrical unarmed thorax and the shortuess of the third antennal joint (shorter than the fourth). The form of the apices of the elytra appears also not to be very different from that of the typical species. The obtuse raised line down the middle of the elytra continues to the produced outer angle of the apical truncature, increasing in elevation.

\section{Graphidessa, nov. gen.}

Gen. Tetrorea (White) affinis et similis, sed differt antennarum scapo gracilius oblongo nec basi subito constricto. Corpus sublineare, sparsim setosum, postice angustatum. Caput exsertum, inter antennas concavum, fronte brevi; oculi grosse granulati, lobis inferioribus magnis, latis : tubera antenuifera supra divaricata sat elevata. Antennæ corpore paullo longiores, infra longe sed sparsim ciliatw, scapo oblongo-subconico, articulo tertio quam quartus, breviori, 5-9 paullulum, 10-11 multo, brevioribus. Thorax sat elongatus, subcylindricus, dorso inæquali et bituberculato, tuberculo lateraii conico, valido, mediano. Elytra anguste oblonga, versus apicem angustata, apice oblique truncata, dorso anteriori depresso, carinula utrinque obtusa centro-basali, penicilla parva sed alta cristata. Sterna inter coxas subplana; acetabula antica extus hiantia, intermedia clausa. Pedes modice elongata; femora clavata ; tibiæ intermediæ extus prope medium sinuatæ, et usque ad apicem hirsutæ.

Belongs to the group Estolides, and in form and markings resembles the New-Zealand genus Tetrorea, from which it differs in the more oblong, less clavate scape, the relatively shorter third joint, and the scantier pilosity of the antennæ, as also in the less strongly clavate femora.

Graphidessa venata, n. sp.

Parva, rufescens, capite thoraceque impunctatis, lituris griseosericeis, elytris utrinque versus apicem lineis subtilibus nonnullis confluentibus maculisque griseo-albis; sparsim nigro-setosa, 
elytris crebre punctulatis versus apicem sublævibus; tibiis apice nigris. Long. $6 \frac{1}{2}$ millim.

Higo.

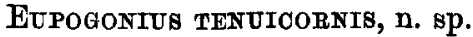

Subcylindricus, nigro-fuscus, tomento ochraceo-fusco submaculatim vestitus, elytris erecte pilosis, antennis et tarsis fulvotestaceis, scapo obscuriori; capite inter antennas concavo; thorace cylindrico, punctato, dorso paullo inæquali, tuberculo laterali mediano parro acuto; elytris linearibus, apice rotundatis sat confertim punctulatis. Long. 5 millim.

Nishimura; Kashiwagi.

Agrees with Eupogonius in every respect, except the more elongate antennæ, which are one third longer than the body, and the joints of which, from the fifth to the eleventh, are rather long and slender instead of being much abbreviated. The proportions of the joints and the form of the scape, however, are the same. The form of head and eyes is the same; the middle tibiæ simple, the anterior and middle acetabula open.

\section{Tebirma, n. gen.}

Gen. Eupogonio subsimilis, sed tibiis intermediis extus conspicue sinuatis, thoracis spina parva laterali acuta. Corpus sublineare, sparsim adpresso-pubéscens et erecte pilosum. Caput exsertum, inter antennas planum; tubera antennifera perparum elevata; frons convexa brevissima; oculi grosse granulati, magni, lobis inferioribus latis convexis. Antennæ filiformes robustæ, infra ciliatæ, corpore multo longiores; scapo oblougoconico, articulis 3-11 longitudine æqualibus nec scapo longioribus. Thorax breviter cylindricus, medio latior, spina postmediaua parva acuta. Elytra subcylindrica, apice obtuse rotuudata. Proet mesosterna inter coxas subplana, illo sat lato; acetabula antica extus hiantia, intermedia aperta. Pedes breves, femora gradatim incrassata; tibiæ intermediæ extus medio sat profunde sinuatæ nec longe hirsutæ; tarsi omnes breves, unguibus divaricatis.

Fits by its structural characters none of the numerous "groupes" of Lacordaire's classification; but is evidently closely allied to the Apodasyides, in which it muy be placed if we admit exceptions to the character of simple middle tibir distinctive of that gruup. 
Terinfa atrofusca, n. sp. (Pl. II. fig. 6.)

Nigro-fusca, fulvo-fusco tenuiter pubescens et pilosa, antennis (scapo excepto) pedibusque piceo-fulvis: supra toto confertim punctulata. Long. 6 millim.

Junsai.

Resembles closely in form and colours Eupogonius tenuicornis.

Cylindrilia, nov. gen.

Gen. Terincece affinis, sed differt thorace inermi, tarsorumque articulo unguiculari longiori et robustiori. Corpus parvum angustum, cylindricum, maculatim tomentosum, haud pilosum. Caput exsertum, inter antennas subconcavum, latum; tubera antennifera perparum elevata; frons convexa, brevis; oculi grosse granulati, lobis inferioribus minoribus, latis. Antennæ corpore longiores, filiformes, infra ciliatæ; scapus oblongo-conicus, articulo quarto longitudine scapo æquali, cæteris omnibus paullo brevioribus inter se subæqualibus. Thorax cylindricus, medio paullo rotundatus ibique transversim convexus. Pro- et mesosterna lata, plana. Acetabula antica extus hiantia, intermedia aperta. Pedes breves; tibiæ intermediæ extus sat profunde sinuatæ, birsutæ; tarsi sat robusti, articulis latis, unguiculari elongato, unguibus divaricatis.

Undoubtedly closely allied to Terincea, and, like that genus, of somewhat doubtful position. The claw-joint of the tarsi is not short. and slender at the base as in Terincea, but elongated, almost as in the Apomecynina, with which the new genus agrees except in the important character of the divaricate claws. The only species known is small and nearly cylindrical.

Cy uindilia grisescens, n. sp.

Fusca, pube adpressa ochraceo-grisea et grisea maculatim vestita, apice macula majori vel fascia lata albo grisea; antennis piceo-rufis, articulis 3-11 basi albis : supra sat confertim, apicem versus sparsius et subseriatim, punctata. Long. $5 \frac{1}{2}$ millim.

Suyama.

Rhopaloscelts unifasciatus, Blessig, Hor. Soc. Ent. Ross. ix. p. 206, t. 8. f. 3.

Junsai ; Sapporo ; Hitoyoshi. Also East Siberia.

Mr. Lewis's specimens do not differ from East-Siberian examples with which I have compared them. 
Rhopaloscelis macdiatus, Bates, Ent. Month. Mag. xiv. (1877) p. 38.

Junsai ; Nikko.

Rhopaloscelis birasciatus, Kraatz, Deutsche ent. Zeit. 1879, p. 113, t. 1. fig. 10.

Sapporo; Junsai. Also East Siberia.

Eryagameiva, nov, gen.

Gen. Polimete (Pascoe), necnon Rhopaloscelidi (Blessig), affinis. Corpus valde elongatum, parum convexum, subtiliter adpresso-pubescens, erecte setosum. Caput exsertum, inter antennas profunde sulcatum ; tubera antennifera separata, divergentia sat elevata; frons lata et brevis : oculi grosse granulati, lobis inferioribus latis. Antennæ elongatæ, filiformes, infra ciliatæ; scapus oblongo-conicus quam articulus 3 brevior, 3 et 4 elongatis subæqualibus, 5-11 gradatim brevioribus. Thorax cylindricus, basi transversim depressus, medio paullulum dilatatus, tuberculo mediano brevissimo, obtuso vel acuto. Fytra maxime elongata, postice angustata, apice oblique truncata, dorso simplici vel ante medium utringue tuberculo spiniformi. Prosternum arcuatum, mesosternum sat latum, antice declive. Acetabula antica angulatim hiantia; intermedia subclausa. Pedes modice elongati; femora gradatim parum clavata, posteriora brevia; tibiæ intermediæ elongatæ graciles, extus medio conspicue sinuatæ; tarsi posteriores elongati, art. primo cæteris 3 conjunctis æquali.

Allied to Potimeta (Pascoe), and, like that genus, having the elytra sometimes with and sometimes without two long spinelike tubercles on the disk. It differs, however, in the upper part of the forehead, which in Polimeta forms a raised transverse elevation produced by the coalescence of the antenniferous tubercles. The genus is allied, on the other hand, to Rhopaloscelis in all essential characters.

Erissamena sapterdina, n. sp.

Nigra, pube adpressa fuscescenti-grisea vestita, erecte nigrosetosa, antennarum articulis 3-11 basi albo-testaceis; thorace sparsim nigro-piperito, tuberculo mediano vix elevato, obtuso; elytris sparsim setifero-punctatis, punetis nigro-marginatis, faseiisque duabus nigris, prima latiori paullo post medium, secunda angustiori undulata ante apicem, dorso inerni, apice dehisoen- 
tibus, oblique truncatis angulo externo subproducto. Long. 10-12 millim.

Chiuzenji ; Usui-toge.

Besides the black setiferous punctures, the elytra have a few simple colourless punctures, mostly in lines.

Eryssamena actia, n. sp.

Ab E. saperdina differt thoracis tuberculis medianis acutis, elytrisque fascia posteriori nulla, antoriori ad suturam late interrupta. Griseo adpresso-pubescens, nigro-punctulata ; antennis piceo-rufis, articulis 3-11 basi albo-testaceis. Long. $12 \frac{1}{2}$ millim.

Usui-toge.

Probably a variety of the preceding.

Eryssamena spinidorsis, n. sp. (Plate II. fig. 10.)

Nigra, griseoad presso-pubescens, nigro-setosa, punctis setiferis nigro-cinctis apud thoracem et elytrorum basin asperatis vel acute tuberculatis; thoracis tuberculis medianis vix elevatis obtusis ; elytris sicut in $E$. saperdina, sed utrinque versus basin tuberculo spiniformi armatis, fasciaque nigra unica paullo post medium; femoribus fortius clavatis. Long. 10-13 millim.

Agematsu; Usui-toge.

Mrccolamta, nov. gen.

Corpus parvum, subcylindricum, ex parte glabrum, sparsim longe setosum. Caput exsertum, fronte convexa, tuberibus antenniferis late separatis; oculi reniformes, grosse granulati. Antennae corpore paullo longiores, sparsim setosæ, scapo brevi, ovato, articulo secundo sat elongato, 3 et 4 cæteris singulatim longioribus. Thorax cylindricus, tuberculo mediano valido acuto. Elytra apice rotundata, carinula centrali-basali plus minusve elevata, dorso anteriori depresso, posteriori convexo. Pro- et mesosterua sat lata et plana; acetabula antica late hiantia, intermedia clausa. Pedes breves; femora clavata; tibiæ intermediæ et posteriores extus ante apicem profunde sinuatæ et setosæ; tarsi breves et lati, posteriorum art. primo quam secundus vix longiori, unguibus divaricatis.

The only described genus to which this new form can be said to be closely allied is Phlyarus (Pascoe) from Borneo. The short ovate form of the antennal scape and deeply sinuated outer edge of the four hinder tibiæ are the same in both genera. 
Mrocolamia clenoÏDes, n. sp. (Plato II. fig. 11.)

Castanea, nitida, antennis pedibusque fulvo-rufis, elytris dimidio basali fulvo-rufo, fascia recta postmediana cano-pubescenti, plaga magna apicali grisea; oculis lobo inferiori angustato; capite et thorace lævibus politis, illo inter antennas subplano, hoc valde convexo; elytris punctato-striatis, carina utrinque subbasali valde elevata penicillata. Long. 4 millim.

Idzu; Nikko.

Micdolamia verRudosa, n. sp.

Pube sericea adpressa vestita, sparsim longe setosa; nigra, elytris fulvis, basi et lateribus nigris; antennis piceo-rufis, scapo articulorumque apicibus fusco-nigris; pedibus nigris, tibiis basi tarsisque rufescentibus; capite inter antennas subconcavo; thorace convexo, dorso inæquali, tuberculato; elytris striatopunctatis, carina subbasali obtusa, interstitiisque alternis seriatim nigro-verrucosis. Long. $3 \frac{1}{2}-4 \frac{1}{2}$ millim.

Suyama; Tokio.

Mrocolamia grabricula, n. sp.

Precedenti proxime affinis; differt corpore supra fere glabro, elytris nigris, plaga communi apiceque fulvis, verrucis pancioribus et minus elevatis. Long. $4 \frac{1}{2}$ millim.

Nikko.

Probably only a variety of $M$. verrucosa, notwithstanding the striking difference in appearance between the two forms, due to the scantiness of the pubescence and the smaller and fewer elytral tubercles.

\section{Cliztosemia, nov. gen.}

Corpus parvum, gracile, subdepressum, subtiliter adpressopubescens, nec setosum. Caput exsertum, inter antenuas coucavum, fronte brevi; oculi reniformes. Antennæ tenues, elongatæ, infra sparsim ciliatæ; scapo brevi, oblongo-conico sed extra basin sinuato-angustato; articulis 3-11, omnibus sat elongatis, gradatim decrescentibus. Thorax elongatus, medio dilatatus, tuberculo mediano valido. Elytra postice angustata, apice dehiscentia singulatim acuminatim-rotuudata, basi (margine humerali elovato excepto) valde depressa, cariua utrinque centro-basali valida, subconica. Pedes sat elongati; femora late dilatata; tibire intermedim extra medium tuberculatæ deinde ad apicem hirsutæ; tarsi postici angusti, articulo primo cæteris tribus æquali.

Undoubtedly allied to Ostedes, Polimeta, aud Rhopaloscelis, but LINN. JOURN.-ZOOLOGY, VOL. XVIII. 
differing in the absence of erect hairs or setw. The lateral tubercles of the thorax are exactly median, and not at all directed rearward but rather forward, and the thorax is narrowed near the base. The genus bas very little in common with Driopea (Pascoe), although the species on which it is founded resembles somewhat in markings $D$. clytina.

Clytosemia pulchra, n. sp. (Plate II. fig. 9.)

Nigra, elytris griseis, fascia lata submediana (antice valde obliquata et suturam haud attingenti), macula magna ante apicem alteraque infrahumerali, nigris; antennis testaceo-fulvis. Long. $5 \frac{1}{2}$ millim.

Nikko.

Acanthocinus stillatus, n. sp.

Griseo adpresso-pubescens, elytris guttis numerosis fasciaque postmediana dentata, nigris; antennis nigria, scapo bnsi griseo, art. 3-11 basi carneo-griseis.

$q$ ovipositor segmento ventrali apice integro.

Long. (oripos. excl.) 9 millim. of $q$.

Chiuzenji ; Junsai ; Nikko.

Callapgous, nov, gen.

Subfam. Acanthoderina pertinet, antennarum scapo pyriformi. Pro hac subfamilia parvus; oblongus sat convexus. Frons lata et brevis. Oculi grosse granulati. Antenno graciles, corpore duplo longiores, subtus parcissime setosæ, articulis 3-4 elongatis, cæteribus brevioribus tenuibus, gradatim decrescentibus. Thorax transversus, tubereulis lateralibus validis acutis, alteris duabus dorsalibus. Elytra basi thoracis duplo latiora, apice rotundata, carinis centro-basalibus perparum elevatis. Pro- et mesosterna aat lata arcuata. Femora abrupte clavata.

1 know of no genus at all nearly allied to this; it has no prima facie resemblance or close affinity to Acanthoderes.

Callapecus guttatos, n. sp. (Plate II. fig. 1.)

Fusco-niger, griseo adpresso-pubescens, elytris guttis numerosis nigris, antennarum articulis 3-11 basi carneo-griseis; thorace confertim punctulato, elytris paullo grossius, hic illic sublineatim, punctatis, interstitiis nonnullis medio disco perparum elevatis; tibiis dimidio basali carmeo-griseo. Long. 8 millim.

Nara. 
Agapanthia angusticoluis, Gyllenhal, Schönh. Syn. Ins. i. 3, App. p. 189.

Junsai, on thistles.

Agrees with East-Siberian examples of this species, referred to Gyllenhal's species by Blessig and Kraatz, except in being of rather larger size and more robust.

Calamobids japonicus, Bates, Ann. \& Mag. $N$. $H$. ser. 4, vol. xii. 1873, p. 383,=Pseudocalamobius id., Kraatz, Deutsche ent. Zeit. 1879, p. 94.

The generic separation of $C$. japonicus from the European species $O$.gracilis, as proposed by Kraatz, is an improvement; C. japonicus differing by its broader bead and non-retracted forehead. But his remark about C. japonicus being a linear Phytceia is seriously misleading. It may be a linear Agapanthia like the European Calamobius ; but to place it in the Phytaciides group would be to make all classification of the Lamiidæ impossible. Ii is probable that Calamobius and Pseudocalamobius are links connecting the Hippopsince with the Agapanthina.

Saperda decemptrotata, Gebler, Reis. ii. 3, p. 186; Blessig, Hora Ent. Ross. ix. 1873, p. 219.

Yezo (Pryer). Two examples of this Siberian species agreeing precisely with the descriptions above eited.

Saperda tetrasticta, Bates, Ann. \&Mag. $\boldsymbol{N}$. $H$. ser. 5 , iv. p. 466.

Junsai.

Saperda sulphurata, Gebler, Bull. Mosc. 1848, p. 405 ; Blessig, Hore Ent. Ross. 1873, p. 223.

Junsai; Nanai. Found throughout Siberia and Manchuria, from Barnaul to Lake Khinka. Feeds on the Rhus.

Belongs to the genus Menesia (Muls.) according to Ganglbauer, Bestimmungs-Tabellen d. Europaïschen Coleop. viii., Cerambycidæ, ii. p. 151.

Saperda octomaculata, Blessig, Horce Ent. Ross. ix. 1873, p. 221.

Junsai. Recorded by Blessig from the Middle Amur in E. Siberia. 
SaPerda sanguinolenta, Thomson.

South and Central Japan and Yezo; on Alnus.

Eutetrapha, nov. gen.

A gen. Saperda differt elytris lateraliter carinatis. Segmenta ventralia 1-4 subæqualia; unguibus simplicibus; elytris apice rotundatis vel breviter et obtuse truncatis.

Closely allied to Saperat tremula and punctata, and differing solely in the carinated sides of the elytra. The genus includes, besides the following, Saperda carinata (Blessig), S. metallescens (Motschulsky), and Glenea ocelota (Bates).

EUTETRAPHA varitcorNis, n. sp.

Saperdce carinata (Blessig) simillima et proxime affinis : differt solum articulis 3-6 apice nigris. Long. 12-20 millim.

Junsai ; on a large Senecro.

Like S. carinata, of linear-oblong form, with carinated sides to the elytra, and clothed with dense ochreous or greyish-ochraceous felt-like pubescence and erect black hairs, the thorax having four black spots (in quadrangle) on the disk and a short fine black line on each flank, the elytra each with seven small angular black spots.

Eutetrapha chrysargirea, n. $\mathrm{sp}$.

E. metallescenti affinis. Squamulis supra aurescenti-viridibus, subtus (cum femoribus) argenteo-auratis splendidissimis, vestita, et passim erecte pilosa. Thorace maculis 4 (in linea transversa), elytris utrinque humeris et carinis, maculisque 4 in linea dispositis (tertia angulata et elongata plerumque cum quarta conjuncta, cæteris rotundatis) nigris, carinis utrinque duabus (inferiori antice abbreviata postice cum superiori conjuncta) validis, margineque incrassato ; antennis nigris partim griseo-pubescentibus; tibiis et tarsis viridi-griseis, illis apice nigris. Long. 12-17 millim. of .

On Oyayama in Higo.

Approaches Glenea more nearly than any of the other species, the first ventral segment being somewhat longer than either of the three following; the apices of the elytra are, however, very obtusely and narrowly truncated.

Paraglenea chrisochloris.-Glenea chrysochloris, Bates, Ann. \& Mag. N. H. ser. 5, vol. iv. p. 467.

Yezo; Chiuzenji. 
Resembles Eutetrapha chrysargyrea in its black markings and the form and colour of the elytral carina; the spots are, however, much larger, the elytra have the external angle of the truncature briefly spinose, and the claws in the male have a short and broad, but sharp tooth at the base, the claws in the female alone being simple.

\section{Paragienea eximia, n. sp.}

Anguste oblongo-linearis, squamulis argenteo-viridibus vestita, erecte (postice brevius) pilosa, media fronte et occipite uigris. Thorace maculis mànis elongatis 4 in linea transversa, elytris utrinque vitta marginali maculisque oblongis subæqualibus et subæquidistantibus 4, nigris, pectore ventroque medio nigris; antenuis pedibusque griseo-nigris,' scapo articuloque tertio extus femoribusque supra cæruleis: supra punctulata, elytris apice singulatim rotundatis, carina laterali obsoleta sed epipleuris verticalibus grosse punctato-striatis ; unguibus $\delta$ $q$ basi late et acute dentatis. Long. 11-12 millim. of 9 .

Junsai ; Sapporo.

Distinguished from the allied metallic squamose species by the large size and regularity of the four black spots of the elytra.

Paraglenea theaphia, $11 . \mathrm{sp}$.

Brevius oblongo-linearis,,nigro-fusca, nitida, adpresso-pubescens et erecte pilosa capite et thorace sulphureis, fronte late thoraceque plaga angulata mediana vittaque laterali, nigris; scutello sulphureo; elytris utrinque maculis 6 (prima basali, secunda rotunda prope basin et suturam, tertia mediana, quarta postmediana elongata obliqua, quinta exteriori punctiformi, sexta ante apicem transversa), vitta angusta submarginali (post humeros incipienti prope apicem cum macula sexta conjuncta) lunulaque apicali, sulphureis; antennis nigris; pedibus pallide rufis: corpore subtus dense cinereo-pubescenti; elytris confertim punctulatis, carina laterali tenui, abbreviata; unguibus (오) basi dente lata, acuta. Long. $10 \frac{1}{2}$ millim.

Sapporo.

Scarcely belongs to Paraglenea, the sides of the elytra not being vertical, aud the carina which separates them from the disk being only slightly elevated and very incomplete. The species has the habit of a true Saperda rather than a Paraglenea, but cannot be included in that genus owing to the toothed base of 
the claws. The legs and tarsi ore remerkably short. I am unwilling to found a new genus on a single example of doubtful sex, in such a group as the Saperdina.

The genus Paraglenea was imperfectly defined by me in Proc. Zool. Soc. 1866, p. 352, and has not been adopted by entomologists. It is, however, sufficientlo distinct from Glenea in the toothed claws in both sexes (the tooth being generally very short) and in the equal leugth of the first four ventral segments.

Glenea Colenda, Thomson, Rev. Zool. 1879, p. 15.

Japan.

I have not seen anything resembling this species in Mr. Lewis's or other collections.

Singalida RUfGgoents, n. sp.

Testaceo-rufa, antennis elytrisque fusco-rufis; thorace antice valde gibboso aspere punctato, elytris creberrime subconfluenter punctulatis, apice utrinque in spinam productis, obsolete costulatis. Long. 14 millim.

Nagasaki.

Differs from S. spinipennis (Lac.), from Ceylon, in the uniform colour of the elytra. In their peculiar structure the two species, judging from Lacordaire's description, perfectly agree.

Stenostola $\Lambda$ RgYrosmicta, n. sp.

Nigra, nitida, erecte pilosa, thorace linea laterali elytrisque maculis utrinque quinque (prima parva basali, secunda paullo posteriori parva oblonga, tertia majori ovata mediana, quarta ovata paullo obliqua longe post medium, quinta parva apicali) argenteo-viridi-tomentosis. Capite crebre punctato, infra oculos viridi-argenteo; thorace parro, cylindrico, basi subconstricto, crebre punctato; elytris discrete punctatis, apices versus lævibus; pectore argenteo-viridi vittato ; antennis nigris; pedibus gracilibus nigris ; tarsis posticis argenteo-viridibus, unguibus basi latissime dentatis. Long. 12 millim.

Chiuzenji.

Agrees with Stenostola nigripes in form and structure, but differs in the elaws being toothed like Oberea.

The species seems to approach Solsky's genus Eumecocera, founded on a Siberian species with uniform silvery-green adpressed pubescence on the elytra; but it has not the fine "setiform" antennæ attributed to Eumecocera, these organs in S. argyrosticta being very similar to those of $\mathbf{S}$. nigripes. 
Stemostola aromata, n. sp.

Linearis, postice paullo angustata, nigra, erecte pilosa, elytris fulvo-castaneis, thorace argenteo-viridi trilineato, linea mediana per scutellum ducta; antennis ( $q$ ) corporelongioribus, basi undique pilosis, articulis 4-11 subæqualibus sat elongatis : capite thoraceque discrete punctatis, hoc relative parvo, cylindrico; elytris apice breviter obtuse truncatis, dorso subplanis sat confertim grosse, lateribus lineatim, punotatis ; unguibus sicut in S. argyrosticta late dentatis. Long. 9 millim.

Higo.

The species does not fit well the genus Stenostola, but it approaches it nearer than it does any other described genus. In form, facies, and punctuation of the sides of the elytra it resembles many Glenece, but differs in its toothed claws and the want of elytral carinæ.

Epiglenea, nov. gen.

Facies gen. Glenea; sed differt unguibus basi late dentatis elytrorumque lateribus haud carinatis confuse punctatis. Corpus cylindricum erecte pilosum, tomentoso-maculatum. Caput thorace latius, fronte infra oculos paullo angustata; oculi convexi. Antennæ corpore longiores, ciliatæ, art. tertio quam scapus paullo longiori, 4-11 elongatis, gradatim decrescentibus. Thorax cylindricus, basi angustatus. Elytra postice parum angustata, supra subplanata, lateribus nullomodo carinatis, omnino sat crebre confuse punctata, apice breviter truncata et utrinque bidentata. Prosternum inter coxas angustissimum; coxæ conicæ exsertæ; mesosternum modice latum. Ventris segmenta 1-4 æqualia, quinto elongato medio sulcato. Tibiæ intermediæ extus subintegræ; tarsi breves, unguiculis divaricatis, $\delta$ q basi latissime dentatis.

The combination of characters above described forbids the location of the species about to be described in any of the known genera of Saperdince. In general form and markings it nearest resembles Glenea, but the claws are toothed as in Oberea and some aberrant Phytecia, and in the two species I have provisionally associated with Stenostola.

Epialenea comes, n. sp.

Nigra, fusco erecte pilosa, fronte margineque oculorum, thoracis vittis tribus, scutello elytrorumque utrinque vitta 
centrali a basi usque ultra medium extensa maculisque transversis duabus inter vittam et apicem, sulphureis, lineola submarginali marginibusque griseis: subtus sulphureo-pubescens; antennis nigris; pedibus rufis. Long. $10 \frac{1}{2}$ millim.

Higo.

Oberea vittata, Blessig, Hore Soc. Ent. Ross. ix. 1873, p. 223.-O. sylvia, Pascoe, Trans. Ent. Soc. ser. 2, iv. p. 261?

Yokohama; Yuyama; Nagasaki.

Agrees with Blessig's description of the Manchurian insect and also with an example I have received from the Amur. The apex of the elytra is truncated, and " mehr oder weniger ausgerandet." In the sinuation of the elytral truncature and the longer or shorter prolongation of the angles of the truncature there are differences in Mr. Lewis's specimens ; but it seems probable the sinuation is stronger in the Japanese than in the continental form.

Oberea hebescens (Bates) is very closely allied to this species, but is distinguishable by its yellow undersurface (except apical ventral segment), $O$. vittata having the breast and middle of the ventral segments always blackish, and by the dark lateral vitta not quite covering the shoulders of the elytra.

Oberea niponensts.-O. japonica, Bates, Ann. \& Mag. N. $H$. 1873 , p. 388 (nom. præoce.).

The name japonica was preoccupied by Thuuberg, whose Saperda japonica appears to be an Oberea. Kraatz considers O. marginella, Bates, to be "probably" Thunberg's S. japonica. The very insufficient diagnosis given by Thunberg appears to have led to his species being omitted by all recent writers on the Longicornia. It is not entered in the Munich Catalogue.

\section{Oberea serioans, n. sp.}

O. marginella, Bates, quoad formam et sculpturam simillima ; differt thorace nigro sat crebre punctato, nitido, corporeque subtus fere toto fusco-nigro. Pro hoc genere brevis, erecte pilosa, elytris subtiliter incumbenti-sericeo-pubescentibus ; capite thoraceque nigris nitidis conspicue punctatis; scutello nigro; elytris sat late sinuato-truncatis, confuse (dorso versus basin tantum subseriatim) punctatis, carinula laterali obsoleta, fulvis, vitta laterali (humeros haud attingenti) nigris, et parte 
apicali interdum fusco suffusa; antennis fulvis, articulis 1-2 nigris, vel fere toto nigris : subtus fusco-nigro. Long. 10-12 millim.

Otaru ; Nanai ; Junsai.

Kraatz suggests that Oberea marginella would be better placed in Nupserha. It is, in fact, like so many other Japanese Longicorns, a connecting link between two genera. The sculpture is more that of an Oberea.

Praolia, nov. gen.

Gen. Serixice affinis et similis; sed differt tarsorum unguibus late et breviter dentatis. Corpus cylindricum, erecte pilosum, elytris sericeo adpresso-pubescentibus. Caput thorace latius; oculi magni, convexi ; vertex et frons plana. Antennæ corpore plusquam duplo longiores, tenuiter filiformes; scapo art. tertio subæquali, cæteris a quarto paullo crescentibus. Thorax breviter cylindricus, postice angustatus. Elytra cylindrica, apice rotundata, seriatim punctata. Pro- et mesosterna angusta sed perspicua; metasterni episterna antice haud dilatata, elongatooblonga, postice subangustata. Ventris segmenta fere æqualia. Femora parum incrassata ; tibiæ intermediæ extus versus apicem sinuatæ ; tarsi breves et lati, unguibus divaricatis basi late et brevissime dentatis.

Allied to the Indo-Malayan genus Serixia, the narrower subcylindrical species of which it much resembles. But Serixia and its allied genera or sections (Iole, Xyaste) have simple claws; in Praotia the tooth of the claws is not like that of Oberea or of Phytacia, but is a dilatation of the base with a distinct angular or pointed edge.

Praolia citrinipes, n. sp. (Plate II. fig. 8.)

Nigra, dense et minus subtiliter sericeo-griseo pubescens et erecte pilosa; capite thoraceque rufis, subnudis, sparsim punctatis, antenuis nigris, articulis a quarto basi pallidis ; pedibus citrinoflavis, tibiis apice et tarsis basi fuscis.

Kashiwagi ; on Celtis.

There remain in Mr. Lewis's collection a few species certainly different from any yet described from Japan, but requiring further, and in some cases more perfect, specimens before they can be described. They are as follows :-- 
1. A Grammoptera, a single specimen, doubtful if not an extreme variety of $G$. amentata.

2. A small species of the group Monohammina, one imperfect example.

3. A species apparently allied to Cylindilla.

4. An imperfect specimen of a species possibly of the group Niphonina.

The following is indeterminable :-

Pogonocherus granulatus, Motsch. Bull. Mosc. 1866, i. p. 174.

From the description it cannot belong to the genus Pogonocherus.

\section{DESORIPTION OF THE PLATES.}

Plate I.

Fig. 1. Xenophyrama purpureum

2. Corennys sericata.

3. Psephactus remiger $\delta$.

4. Fustrangalis distenioides 우.

5. Lemula decipiens.

6. Toxotinus longicornis.

7. Encyclops olivaceus.

8. Pyrrhona læticolor.

9. Phlyctidola metallica.

10. Dolophrades terrenus.

11. Paraclytus excultus.

12. Aglaophis colobotheoïdes.
Puate II.

Fig. 1. Callapcecus guttatus.

2. Xenicotela fuseula.

3. Mesosella simiola.

4. Nanohammus rufescens.

5. Apalimna liturata.

6. Terinæa atrofusca.

7. Xylariopsis mimica.

8. Praolia citrinipes.

9. Olytosemia pulohra.

10. Eryssamena spinidorsis.

11. Miccolamia cleroïdes.

12. Mecynippus pubicornis.

On the Influence of Wave-currents on the Fauna inbabiting Shallow Seas. By Arthor R. Hunt, M.A., F.G.S. (Communicated by Dr. J. Gwyn JeFreyrs, F.R.S., F.I.S.)

[Read 5th June, 1884.]

THE action of waves below the surface of the water decreases so rapidly as the depth increases that naturalists have been in the habit of neglecting submarine wave-action altogether. In proof of this I may refer to Sir Charles Lyell's assertion that " the agitation caused by waves, even during storms, extends to a very slight depth" ('Elements of Geology,' 6th ed.p. 20); and to Dr. Günther's statement that "the agitation of the water caused by 
H.W Bates .
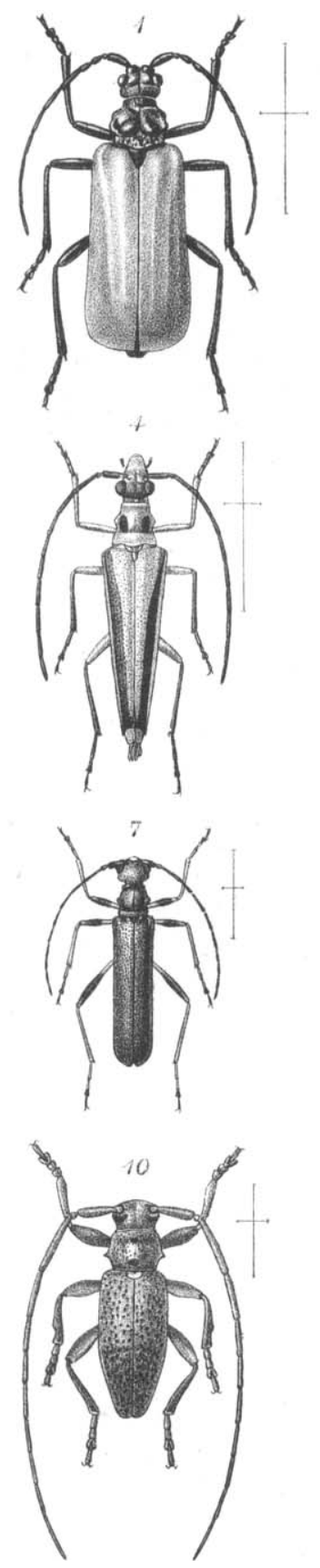

W.Purkiss lith.
Linn Soc. Journ. Zoom, Vos, XVIII. Pu. I
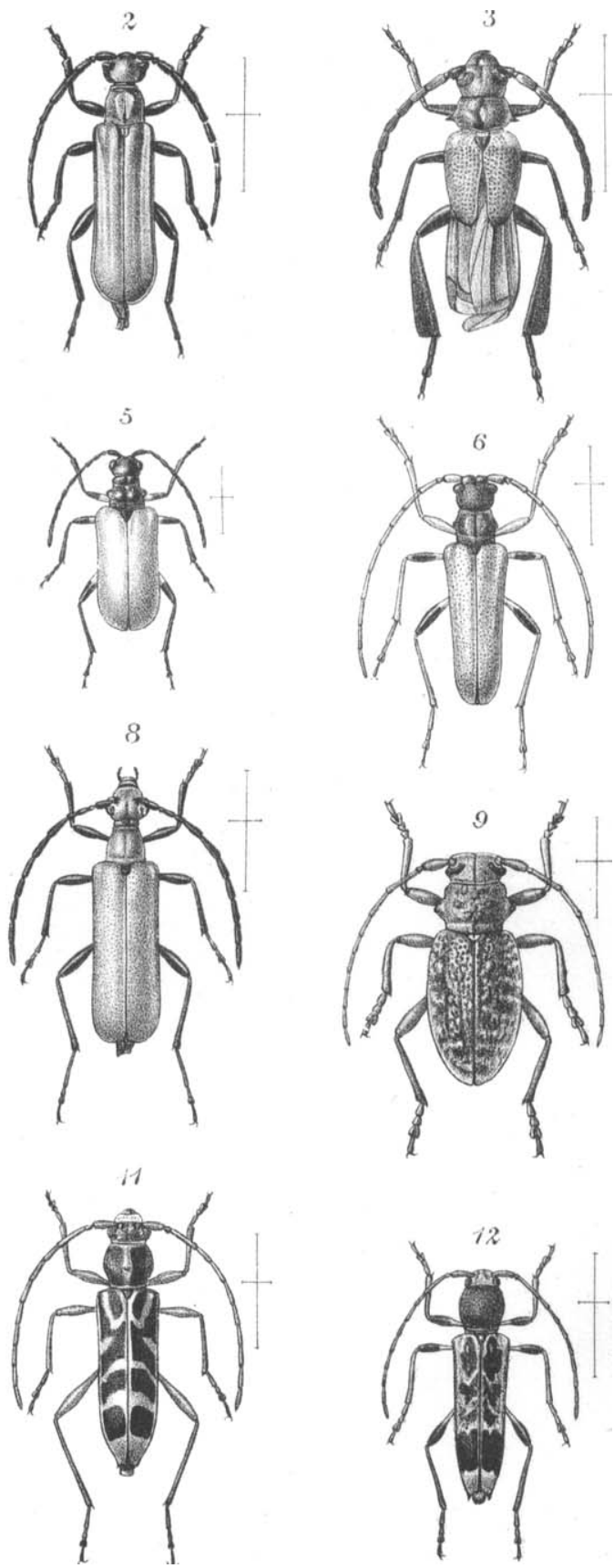

Hanhart imp.

NEW LIONGICORNS FROM JAPAN 

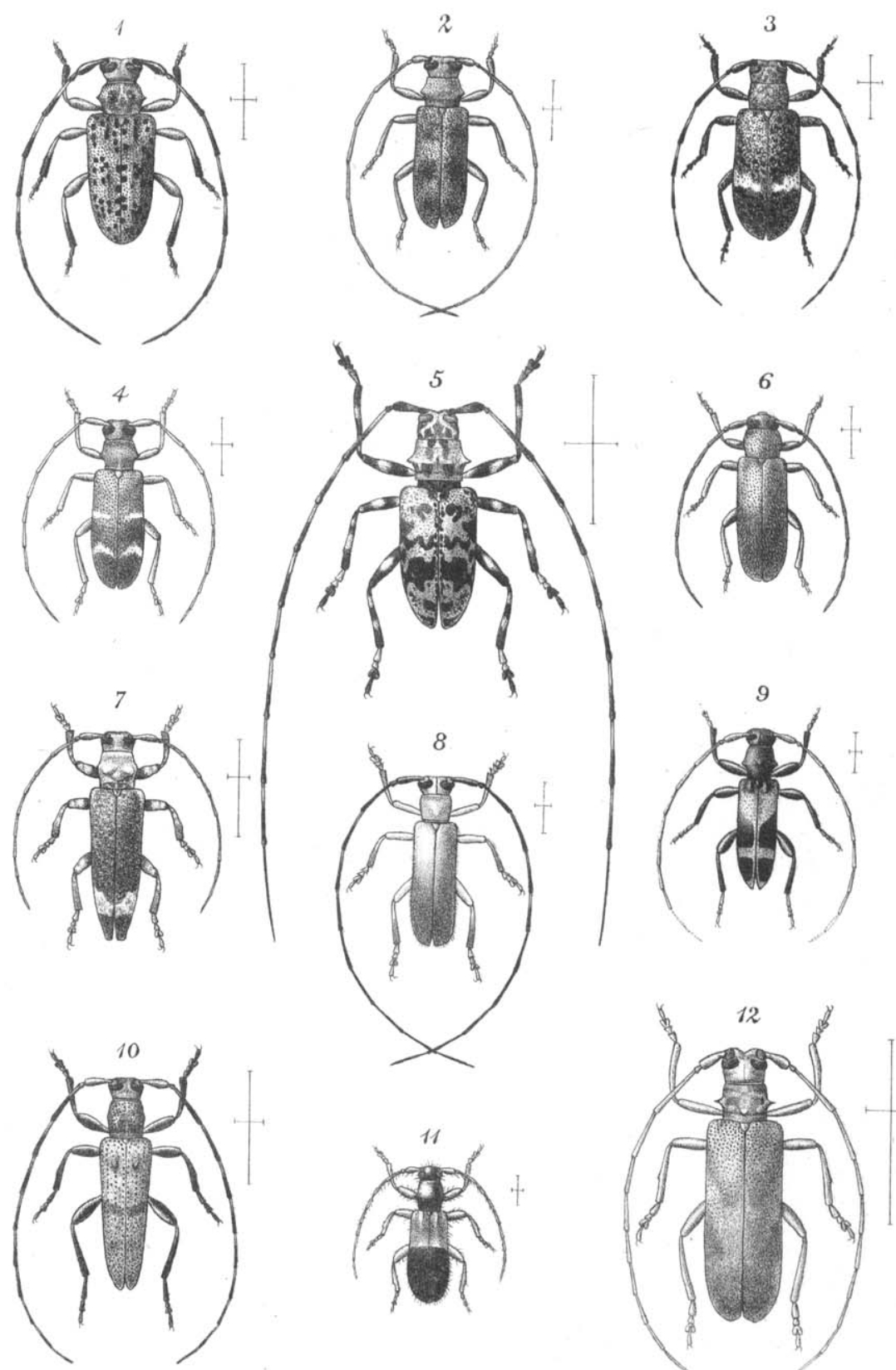

W.Purkiss ith

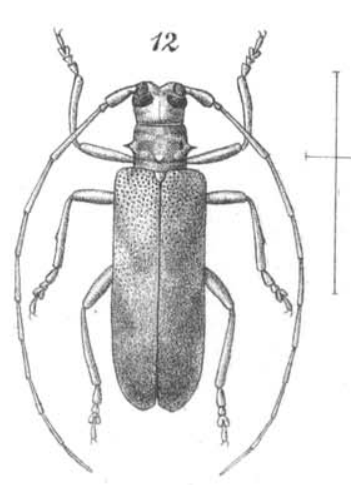

W.Purkiss deh

NEW LONGICORNS FROM JAPAN

Hanhart imp 